\title{
Heavy metal load and effects on biochemical properties in urban soils of a medium-sized city, Ancona, Italy
}

\author{
Dominique Serrani (D) Franco Ajmone-Marsan • Giuseppe Corti • \\ Stefania Cocco • Valeria Cardelli • Paola Adamo
}

Received: 16 April 2021 / Accepted: 17 September 2021 / Published online: 6 October 2021

(C) The Author(s) 2021

\begin{abstract}
Urban soils are often mixed with extraneous materials and show a high spatial variability that determine great differences from their agricultural or natural counterparts. The soils of 18 localities of a medium-sized city (Ancona, Italy) were analysed for their main physicochemical and biological properties, and for chromium $(\mathrm{Cr})$, copper $(\mathrm{Cu})$, cobalt $(\mathrm{Co})$, lead $(\mathrm{Pb})$, nickel $(\mathrm{Ni})$, zinc $(\mathrm{Zn})$, and mercury $(\mathrm{Hg})$ total content, distribution among particle-size fractions, and extractability. Because of the absence of thresholds defining a hot spot for heavy metal pollution in urban soils, we defined a "threshold of attention" (ToA) for each heavy metal aiming to bring out hot spot soils where it is more impellent to intervene to
\end{abstract}

Supplementary Information The online version contains supplementary material available at https://doi.org/10.1007/ s10653-021-01105-8.

D. Serrani $(\bowtie) \cdot$ G. Corti $\cdot$ S. Cocco $~ V$ V. Cardelli Department of Agriculture, Food and Environmental Sciences, Polytechnic University of Marche, Via Brecce Bianche 10, 60131 Ancona, Italy

e-mail: d.serrani@univpm.it

F. Ajmone-Marsan

Department of Agriculture, Forest and Food Sciences, University of Turin, Largo Paolo Braccini 2, 10095 Grugliasco, Italy

P. Adamo

Department of Agricultural Sciences, University of Naples Federico II, Via Università 100, 80055 Portici, Italy mitigate or avoid potential environmental concerns. In several city locations, the soil displayed sub-alkaline $\mathrm{pH}$, large contents of clay-size particles, and higher TOC, total $N$, and available $P$ with respect to the surrounding rural areas, joined with high contents of total heavy metals, but low availability. The $\mathrm{C}$ biomass, basal respiration, $\mathrm{qCO}_{2}$, and enzyme activities were compared to that detected in the near rural soils, and results suggested that heavy metals content has not substantially compromised the soil ecological services. We conclude that ToA can be considered as a valuable tool to highlight soil hot spots especially for cities with a long material history and, for a proper risk assessment in urban soils, we suggest considering the content of available heavy metals (rather than the total content) and soil functions.

Keywords Urban soil pollution - Heavy metals . Microbial biomass $\mathrm{C} \cdot$ Enzyme activities $\cdot$ Soil pollution benchmark

\section{Introduction}

Urban soils are soils of urban and suburban environments intensively disturbed by human activity (Morel et al., 2005; Pouyat et al., 2020) and that show a remarkable spatial heterogeneity (De Kimpe et al. 2000). Historically, urban soils were ignored in soil studies, but in the last decades, they have gained 
attention because of their importance for human health in the city environment (Rossiter, 2007). In addition, the urban population was $34 \%$ of the total global population in 1960 , amounted to $54 \%$ in 2014 , and is expected to be $68 \%$ in 2050 (UN, 2018; WHO, 2016). Because of this, urban soil pollution may represent a global growing environmental problem (FAO \& ITPS 2015; Li et al., 2018).

Among the several types of pollutants, heavy metals are the most frequent ones in urban soils (Kumar \& Hundal, 2016). According to numerous studies (e.g. Ajmone-Marsan \& Biasioli, 2010; Sodango et al., 2018; Wuana \& Okieimen, 2011; Xiao et al., 2017; Zhang \& Whang 2020), the main sources of heavy metals in urban soil pollution are metallurgical industry, mining activities, fossil fuel consumption, vehicular traffic, irrigation, waste incineration, and, to a certain extent, the use of fertilizers and agrochemicals. The urban intensity and concentration of the emission sources are often higher than elsewhere, with a redistribution of heavy metals and other pollutants by wind and atmospheric deposition even at considerable distances from the source (Liao et al., 2020; Liu et al., 2016; Wei \& Yang, 2010).

Because of the relationships between soil and the rest of the ecosystem, studies investigated the potential risk that heavy metals represent for human health in the urban environment (e.g. Ajmone-Marsan \& Biasioli, 2010; Bugnot et al., 2019; Francová et al., 2016; Li et al., 2018; Luo et al., 2015). To assess their potential translocation to other environmental compartments, Ajmone-Marsan et al. (2008) investigated the distribution of potentially toxic heavy metals in soils of five European cities, while, in other cities, the distribution of potentially toxic heavy metals across the city or urban parks was assessed by Madrid et al. (2006), Simon et al. (2013) and Pons-Branchu (2015). In China, heavy metals pollution and translocation has become a serious environmental problem with the intense industrialization and urbanization of the last two decades, and the situation is monitored all over the country (e.g. Cheng et al., 2014; Hu et al., 2020; Li et al., 2014, 2017; Luo et al., 2012; Tepanosyan et al., 2016; Yuan et al., 2014, 2021). However, point sources may have a harsh impact, but it is the diffuse heavy metal pollution that causes the most severe problems to the soil biochemical and microbiological properties (e.g. Lorenz \& Kandeler, 2005; Naylo et al., 2019; Papa et al., 2010; Unda-Calvo et al., 2019).
Because of environmental and human health concern, many countries adopted regulatory guidelines defining the limits for soil metal(loid)s in soil. Examples are UK (Environment Agency, 2020), France (Darmendrail, 2003), China (Shi-bao et al., 2018), USA (United States Environmental Protection Agency, 2021), Russia and Netherland (Vodyanitskii, 2016), and Italy (Gazzetta Ufficiale No. 293, 15 December 1999). However, guidelines often do not differentiate urban soils from other types of soil. Instead, limits for heavy metals contaminating urban soils would be useful for cities with long time of human settlement where metallurgy, construction, and many other human activities have accumulated heavy metals in soil for centuries or millennia. Because of this, after a thorough evaluation of the microbial soil functionality of soils differently affected by heavy metal concentrations in a city with a long human history (Ancona, Italy), we propose the "threshold of attention", a limit for heavy metals in urban soils that can change in time depending on the sources of pollution and the remediation measures activated.

Therefore, the present study aimed at: $i$ ) assessing the total and available concentrations of heavy metals ( $\mathrm{Co}, \mathrm{Cr}, \mathrm{Cu}, \mathrm{Hg}, \mathrm{Ni}, \mathrm{Pb}$, and $\mathrm{Zn}$ ) in the soils of a medium-sized city (Ancona, Italy); (ii) examining the effect of heavy metals on soil biochemical properties as proxies for soil functionality [microbial biomass $\mathrm{C}$ content, cumulative $\mathrm{CO}_{2}$ respiration, metabolic quotient, and the activities of four of the most active soil enzymes (alkaline phosphatase, acid phosphatase, $\beta$ glucosidase, and urease)]; (iii) proposing a "threshold of attention" for heavy metal pollution in urban soils. The potential of this study approach is to better assess environmental risks related to the presence of heavy metals in the soils of old-settled cities.

\section{Materials and methods}

\section{General characteristics of Ancona}

The city of Ancona is located on the eastern coast of central Italy (Fig. 1). Because of its strategic position on the Adriatic Sea, the area of the city has been populated since the Bronze Age. Nowadays, the Municipality of Ancona has a surface of $\approx 125 \mathrm{~km}^{2}$, a population of $\approx 100300$ inhabitants, and a population density of $\approx 803$ inhabitants per $\mathrm{km}^{2}$. The city has 


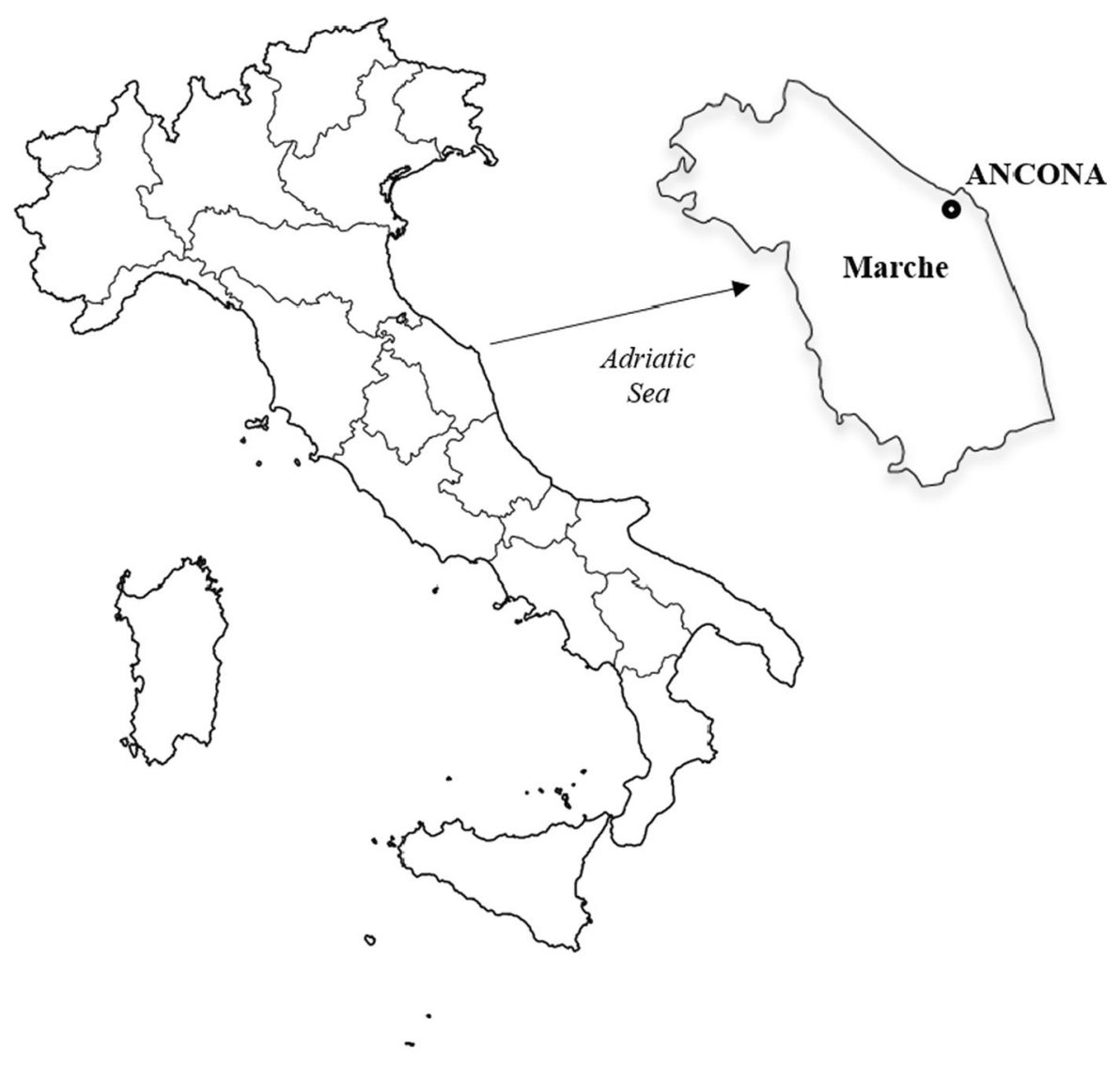

Fig. 1 Map of Italy with localization of the Ancona City in Marche region

railway and bus stations and hosts the main harbour of the Adriatic Sea and other touristic facilities that connect Italy to Balkan countries and Greece, with strong trade activities (fishery) that have largely influenced the economic and urban development. At $\approx 10 \mathrm{~km}$ from the city in the W-NW direction, there is an oil refinery $\left(43^{\circ} 38^{\prime} 17.47^{\prime \prime N}, 13^{\circ} 22^{\prime} 45.44^{\prime \prime} \mathrm{E}\right)$. In the last decade, technical investigations reported that the refinery has no considerable socio-environmental impact farther than $4-5 \mathrm{~km}$ from the plant (ARPAM, 2012; Corti et al., 2010). It is therefore sufficiently far to exclude any influence on the city.

The city has a typical sub-Mediterranean climate, with a mean annual air temperature of $13.6{ }^{\circ} \mathrm{C}$, and a mean annual precipitation of $780 \mathrm{~mm}$ and receives dominant and strong winds from $\mathrm{N}$ and NW (Brecciaroli et al., 2012). The urban area is spread on finetextured Plio-Pleistocene carbonaceous marine and fluvio-marine sediments, a lithologic unit present in the coastal and peri-coastal area of the Marche region (Cocco et al., 2007, 2013), forming a series of gentle hills with maximum altitudes of $\approx 140 \mathrm{~m}$.

Selected locations, soil collection, and soil processing

This investigation was carried out on the ancient and more densely populated part of the city, where also harbour, railway, and bus station are settled, and where large gardens are few. Within the ancient city, industrial activities were present until the 1990s; since then, they have been moved to scarcely inhabited outlying districts. Hence, 18 locations among the most representative ones of the city were selected, taking into consideration three urban land uses: recreational areas (6 locations), flowerbeds (11 locations), and private gardens (1 location) (Fig. 2). The main physiographic characteristics of each location are reported 


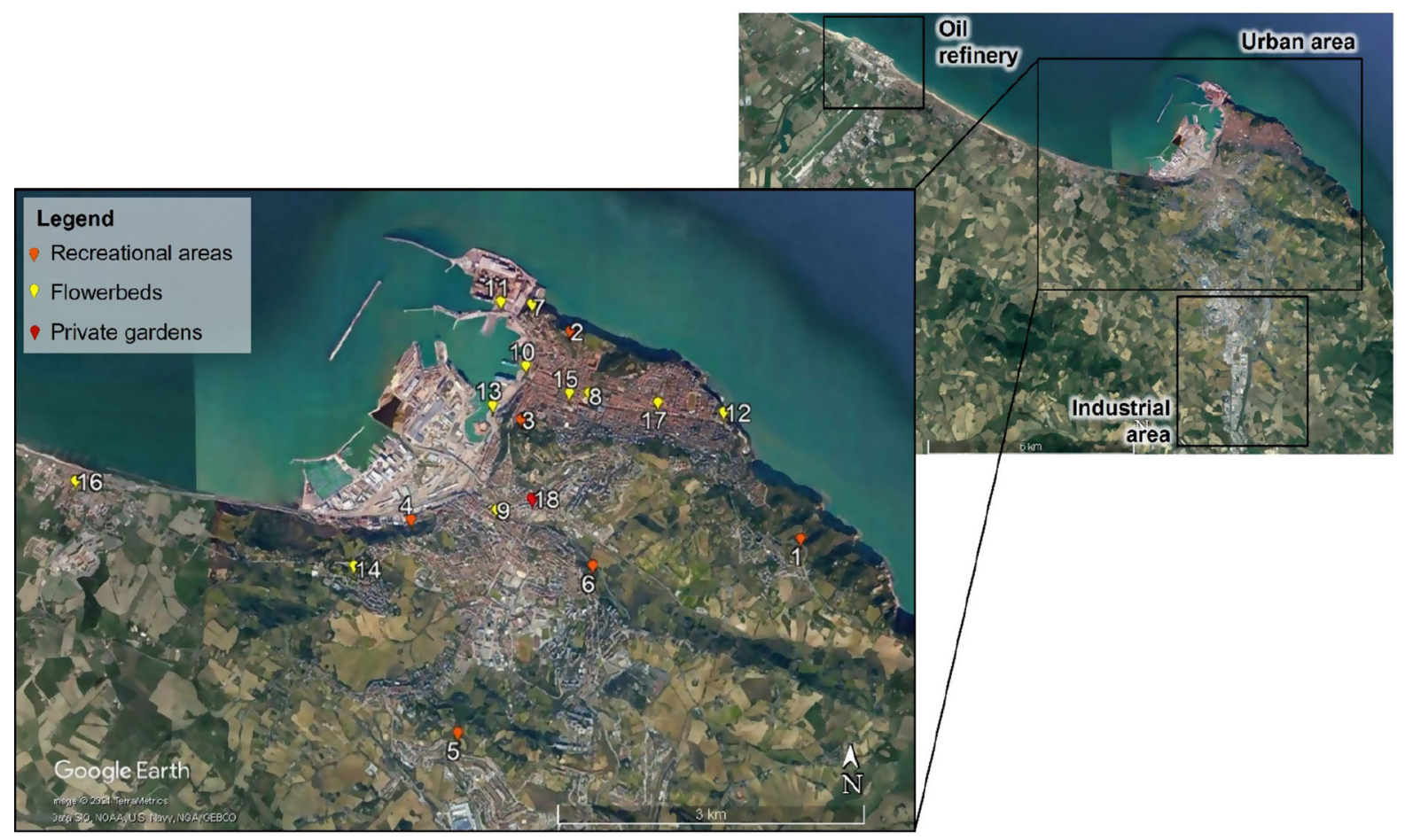

Fig. 2 Sites localization of the urban soils collected at Ancona City (central Italy). Recreational areas: 1. Altavilla park; 2. Cardeto park; 3. Cittadella park; 4. Palombella park; 5. Unicef park; 6. Villa Beer park. Flowerbeds: 7. Cathedral; 8. Cavour square; 9. Corso Carlo Alberto (avenue); 10. Harbour, close to

in Table 1. We are aware of the great dimensional heterogeneity and spatial variability of the studied locations but, in selecting them, we wanted to cover most of the situations where the soil is present in the city, as also suggested by Pouyat et al., $(2017,2020)$ and Burghardt (2017). Further, our aim was not to assess the spatial variability of the soil within locations, but to estimate the level of heavy metal concentrations within the city. Further details on the selected locations are reported at point 1 of Supplementary Materials).

At each location, three sampling sites were identified at the vertex of a triangle with sides of 6-8 m. Concerning with the depth of sampling, we collected the soil samples from the superficial $5 \mathrm{~cm}$ of soil with the purpose to collect the soil portion most enriched of heavy metals derived from allochthonous additions, as reported by Ljung et al. (2006) and Sun (2010). Therefore, from each site, a soil sample was taken by collecting the soil inside a $30 \times 15 \mathrm{~cm}$ frame to the the customs house; 11 . Harbour, close to the Trajan arch; 12. Passetto neighbourhood; 13. Porta Pia neighbourhood; 14. Posatora neighbourhood; 15. Stamira square; 16. Torrette neighbourhood; 17. Viale della Vittoria. Private gardens: 18. Corso Carlo Alberto.

depth of $5 \mathrm{~cm}(\approx 2 \mathrm{~kg})$. The three samples collected from each location were kept separately. Once in the laboratory, half of each sample at field moisture conditions was sieved through $2 \mathrm{~mm}$ to separate the skeletal fraction and maintained at field moisture at $4{ }^{\circ} \mathrm{C}$ for maximum one week before biochemical analyses. The other half of each sample was air-dried and sieved at $2 \mathrm{~mm}$. All analyses were run on the $<2 \mathrm{~mm}$ fraction. During sample sieving, allochthonous materials like building debris, plastic, or scrap metal have never been found.

Physicochemical analyses

The $\mathrm{pH}$ was determined potentiometrically in water at a 1:2.5 solid:liquid (w:v) ratio. Particle-size distribution was determined after the dissolution of organic cements with $\mathrm{NaClO}$ at $\mathrm{pH} 9$ (Lavkulich \& Wiens, 1970); sand was recovered by sieving at $0.05 \mathrm{~mm}$, while silt was separated from clay by sedimentation. 
Table 1 Sampling sites with details about location, physiography, soil use, and vegetation of the soils from different locations of the city of Ancona (central Italy)

\begin{tabular}{|c|c|c|c|c|c|}
\hline Location & $\begin{array}{l}\text { Geographic } \\
\text { coordinates }\end{array}$ & Extension & $\begin{array}{l}\text { Slope, } \\
\%\end{array}$ & Vegetation & Observations \\
\hline \multicolumn{6}{|c|}{ Recreational areas* } \\
\hline Altavilla park & $\begin{array}{l}43^{\circ} 36^{\prime} 11.12^{\prime \prime} \mathrm{N} \\
13^{\circ} 32^{\prime} 35.02^{\prime}, \mathrm{E}\end{array}$ & 1.2 ha & $<0.5$ & $\begin{array}{l}\text { Populus alba L., Fraxinus ornus L., and } \\
\text { Robinia pseudoacacia L }\end{array}$ & \\
\hline Cardeto park & $\begin{array}{l}43^{\circ} 37^{\prime} 20.84^{\prime \prime} \mathrm{N} \\
13^{\circ} 30^{\prime} 53.03^{\prime}, \mathrm{E}\end{array}$ & 15 ha & $<0.5$ & $\begin{array}{l}\text { Mediterranean vegetation with Robinia } \\
\text { pseudoacacia L. and Ailanthus altissima } \\
\text { (Mill.) Swingle }\end{array}$ & \\
\hline Cittadella park & $\begin{array}{l}43^{\circ} 36^{\prime} 50.70^{\prime}{ }^{\prime} \mathrm{N} \\
13^{\circ} 30^{\prime} 30.93^{\prime}, \mathrm{E}\end{array}$ & 14 ha & 30 & $\begin{array}{l}\text { Mixed meadow with Cupressus } \\
\text { sempervirens L. and Pinus halepensis } \\
\text { Mill }\end{array}$ & \\
\hline Palombella park & $\begin{array}{l}43^{\circ} 36^{\prime} 17.31^{\prime \prime} \mathrm{N} \\
13^{\circ} 29^{\prime} 41.84^{\prime \prime} \mathrm{E}\end{array}$ & 10 ha & 30 & $\begin{array}{l}\text { Rarefied grass; close to a dismissed brick } \\
\text { factory }\end{array}$ & \\
\hline Unicef park & $\begin{array}{l}43^{\circ} 35^{\prime} 07.74^{\prime \prime} \mathrm{N} \\
13^{\circ} 30^{\prime} 02.96^{\prime} \mathrm{E}\end{array}$ & 6 ha & $<0.5$ & $\begin{array}{l}\text { Mixed meadow with Quercus ilex L. and } \\
\text { Laurus nobilis L }\end{array}$ & \\
\hline Villa Beer park & $\begin{array}{l}43^{\circ} 36^{\prime} 02.15^{\prime}{ }^{\prime} \mathrm{N} \\
13^{\circ} 31^{\prime} 02.53^{\prime}, \mathrm{E}\end{array}$ & 5 ha & $<0.5$ & $\begin{array}{l}\text { Mixed meadow with Fraxinus ornus L., } \\
\text { Pinus halepensis Mill., Quercus ilex L., } \\
\text { and Viburnum tinus L }\end{array}$ & \\
\hline \multicolumn{6}{|l|}{ Flowerbeds } \\
\hline Cathedral & $\begin{array}{l}43^{\circ} 37^{\prime} 30.04^{\prime}{ }^{\prime} \mathrm{N} \\
13^{\circ} 30^{\prime} 35.85^{\prime}, \mathrm{E}\end{array}$ & $330 \mathrm{~m}^{2}$ & $<0.5$ & $\begin{array}{l}\text { Mixed meadow with Pittosporum tobira } \\
\text { (Thunb.) W.T. Aiton and Robinia } \\
\text { pseudoacacia L }\end{array}$ & \\
\hline Cavour square & $\begin{array}{l}43^{\circ} 36^{\prime} 59.85^{\prime \prime} \mathrm{N} \\
13^{\circ} 31^{\prime} 01.25^{\prime \prime} \mathrm{E}\end{array}$ & 1.1 ha & $<0.5$ & $\begin{array}{l}\text { Rarefied grass with Phoenis canariensis } \\
\text { Chabaud and Tilia platyphyllos Scop }\end{array}$ & \\
\hline $\begin{array}{l}\text { Corso Carlo } \\
\text { Alberto } \\
\text { (avenue) }\end{array}$ & $\begin{array}{l}43^{\circ} 36^{\prime} 20.43^{\prime}{ }^{\prime} \mathrm{N} \\
13^{\circ} 30^{\prime} 19.90^{\prime} \mathrm{E}\end{array}$ & $\begin{array}{l}1500 \mathrm{~m}^{2} \\
(2.5 \mathrm{~m} \\
\text { wide, } \\
600 \mathrm{~m} \\
\text { long) }\end{array}$ & $<0.5$ & $\begin{array}{l}\text { Pittosporum tobira (Thunb.) W.T. Aiton } \\
\text { and Platanus occidentalis L }\end{array}$ & Very congested area \\
\hline $\begin{array}{l}\text { Harbour, close } \\
\text { to the customs } \\
\text { house }\end{array}$ & $\begin{array}{l}43^{\circ} 37^{\prime} 09.10^{\prime}{ }^{\prime} \mathrm{N} \\
13^{\circ} 30^{\prime} 33.03^{\prime}, \mathrm{E}\end{array}$ & $89 \mathrm{~m}^{2}$ & 20 & Pittosporum tobira (Thunb.) W.T. Aiton & Very congested area \\
\hline $\begin{array}{l}\text { Harbour, close } \\
\text { to the Trajan } \\
\text { arch }\end{array}$ & $\begin{array}{l}43^{\circ} 37^{\prime} 30.96^{\prime \prime} \mathrm{N} \\
13^{\circ} 30^{\prime} 21.76^{\prime}, \mathrm{E}\end{array}$ & $368 \mathrm{~m}^{2}$ & $<0.5$ & Mixed meadow & \\
\hline $\begin{array}{l}\text { Passetto } \\
\text { neighbourhood }\end{array}$ & $\begin{array}{l}43^{\circ} 36^{\prime} 53.28^{\prime}, \mathrm{N} \\
13^{\circ} 32^{\prime} 01.80^{\prime}, \mathrm{E}\end{array}$ & $289 \mathrm{~m}^{2}$ & $<0.5$ & $\begin{array}{l}\text { Mixed meadow with Quercus ilex L. and } \\
\text { Laurus nobilis L }\end{array}$ & \\
\hline $\begin{array}{l}\text { Porta Pia } \\
\text { neighbourhood }\end{array}$ & $\begin{array}{l}43^{\circ} 36^{\prime} 55.79^{\prime}{ }^{\prime} \mathrm{N} \\
13^{\circ} 30^{\prime} 18.12^{\prime \prime} \mathrm{E}\end{array}$ & $472 \mathrm{~m}^{2}$ & $<0.5$ & $\begin{array}{l}\text { Mixed meadow, Pittosporum tobira } \\
\text { (Thunb.) W.T. Aiton and Phoenis } \\
\text { canariensis Chabaud }\end{array}$ & \\
\hline $\begin{array}{l}\text { Posatora } \\
\text { neighbourhood }\end{array}$ & $\begin{array}{l}43^{\circ} 36^{\prime} 02.01^{\prime \prime} \mathrm{N} \\
13^{\circ} 29^{\prime} 16.66^{\prime}, \mathrm{E}\end{array}$ & $300 \mathrm{~m}^{2}$ & $<0.5$ & $\begin{array}{l}\text { Mixed meadow with Pinus pinea L., } \\
\text { Nerium oleander L., Buddleja davidii } \\
\text { Franch., Pittosporum tobira (Thunb.) } \\
\text { W.T. Aiton, and Laurus nobilis L }\end{array}$ & \\
\hline Stamira square & $\begin{array}{l}43^{\circ} 36^{\prime} 59.92^{\prime}, \mathrm{N} \\
13^{\circ} 30^{\prime} 52.51^{\prime}, \mathrm{E}\end{array}$ & 0.12 ha & $<0.5$ & $\begin{array}{l}\text { Mixed meadow with Pittosporum tobira } \\
\text { (Thunb.) W.T. Aiton }\end{array}$ & \\
\hline $\begin{array}{l}\text { Torrette } \\
\text { neighbourhood }\end{array}$ & $\begin{array}{l}43^{\circ} 36^{\prime} 30.04^{\prime \prime} \mathrm{N} \\
13^{\circ} 27^{\prime} 11.99^{\prime} \mathrm{E}\end{array}$ & 0.19 ha & 5 & $\begin{array}{l}\text { Mixed meadow with Aesculus } \\
\text { hippocastanum L }\end{array}$ & Very congested area \\
\hline
\end{tabular}


Table 1 continued

\begin{tabular}{|c|c|c|c|c|c|}
\hline Location & $\begin{array}{l}\text { Geographic } \\
\text { coordinates }\end{array}$ & Extension & $\begin{array}{l}\text { Slope, } \\
\%\end{array}$ & Vegetation & Observations \\
\hline $\begin{array}{l}\text { Viale della } \\
\text { Vittoria }\end{array}$ & $\begin{array}{l}43^{\circ} 36^{\prime} 56.59^{\prime}{ }^{\prime} \mathrm{N} \\
13^{\circ} 31^{\prime} 32.29^{\prime} \mathrm{E}\end{array}$ & $\begin{array}{l}2000 \mathrm{~m}^{2} \\
(2 \mathrm{~m} \\
\text { wide, } \\
1000 \mathrm{~m} \\
\text { long) }\end{array}$ & $<0.5$ & Mixed meadow with Ulmus minor Mill & $\begin{array}{l}\text { Very congested area. } \\
\text { Soil was replaced two } \\
\text { years before the } \\
\text { sampling }\end{array}$ \\
\hline \multicolumn{6}{|c|}{ Private gardens } \\
\hline $\begin{array}{l}\text { Corso Carlo } \\
\text { Alberto }\end{array}$ & $\begin{array}{l}43^{\circ} 36^{\prime} 24.22^{\prime}{ }^{\prime} \mathrm{N} \\
13^{\circ} 30^{\prime} 35.85^{\prime}, \mathrm{E}\end{array}$ & $190 \mathrm{~m}^{2}$ & $<0.5$ & $\begin{array}{l}\text { Vegetable garden and mixed meadow with } \\
\text { sparse roses (Rosa spp.) and hedges of } \\
\text { Buxus sempervirens L }\end{array}$ & $\begin{array}{l}\text { Vegetable gardens, } \\
\text { flowers, bushes }\end{array}$ \\
\hline
\end{tabular}

\footnotetext{
*The extension of recreational areas refers to the total park surface within which soil samples were collected in the surrounding of children's games
}

The content of active carbonate was estimated by the $\mathrm{KMnO}_{4}$ method (Drouineau, 1942), while that of total carbonates was measured using the gas volumetric method (Balázs et al., 2005; ISO, 10693, 1995). The content of total organic C (TOC) was estimated by wet digestion (Nelson \& Sommers, 1996), and the total N was determined by a dry combustion analyser (Carlo Erba EA1110). Available $P$ was estimated according to Olsen et al. (1954). The exchangeable cations were determined with a $0.2 \mathrm{M} \mathrm{BaCl}_{2}$ solution at $\mathrm{pH} 8.1$ (solid:liquid ratio of $1: 10$ ) and the solution was analysed with flame mode for $\mathrm{Ca}, \mathrm{Mg}, \mathrm{K}$, and $\mathrm{Na}$ by atomic absorption spectrophotometry (model AA6300, Shimadzu, Germany).

The mineralogical assemblage was evaluated by X-ray diffractometry on manually compressed powdered samples. The diffractometer was a Philips PW 1830, which produced a Fe-filtered Co K $\alpha 1$ radiation operating at $35 \mathrm{kV}$ and $25 \mathrm{~mA}$. After identification of the minerals on the basis of their characteristic peaks, a semi-quantitative assessment of the mineralogical composition was obtained by estimating the area of the peak by multiplying the peak height by its width at half-height. Calcite content was measured by dissolution (Bundy \& Bremner, 1972). To determine the $\mathrm{Cr}$ and $\mathrm{Ni}$ contents of serpentine minerals, soil samples were gently fragmented and sieved at $1 \mathrm{~mm}$ to collect the 1-2 mm fraction. By a magnifying lens, from this fraction we separated aliquots of 100 to $300 \mathrm{mg}$ rich of serpentine mineral. These aliquots were washed with diluted $(0.25 \mathrm{M}) \mathrm{HCl}$ solution, rinsed with distilled water, ground, and analysed by X-ray diffraction; the aliquots with an estimated serpentine content larger than $90 \%$ were retrieved and treated with aqua regia (see below) to determine the lattice content of $\mathrm{Cr}$ and Ni.

For each soil sample, the pseudo-total concentration of $\mathrm{Cr}, \mathrm{Cu}, \mathrm{Co}, \mathrm{Pb}, \mathrm{Ni}, \mathrm{Zn}$, and $\mathrm{Hg}$ was obtained by dissolution of the specimens in aqua regia according to the following protocol: subsamples of $0.5 \mathrm{~g}$ were finely ground in an agate mortar and placed into a 120-mL Teflon-PFA microwave digestion vessel, added of $12 \mathrm{~mL}$ of aqua regia (1:24 soil:solution ratio) and digested at $0.69 \times 10^{6} \mathrm{~Pa}$ for $10 \mathrm{~min}$. The solution was then filtered through a Whatman 42 filter, transferred to $100-\mathrm{mL}$ volumetric flasks, and brought to volume with distilled water. The contents of heavy metals were determined in the solution by inductively coupled plasma mass spectrometry (ICP-MS, Agilent 7500ce, Waldbronn, Germany). The same protocol was used to determine $i$ ) the pseudo-total concentrations of $\mathrm{Co}, \mathrm{Cr}, \mathrm{Cu}, \mathrm{Hg}, \mathrm{Ni}, \mathrm{Pb}$, and $\mathrm{Zn}$ in clay, silt, and sand separates $(<2,2-50$, and 50-2000 $\mu \mathrm{m}$ fractions, respectively) obtained by wet sieving and sedimentation of samples submerged in water for $2 \mathrm{~h}$ (no cement dissolution); and ii) the $\mathrm{Cr}$ and $\mathrm{Ni}$ contents of serpentine minerals obtained as mentioned above (in this case, we used aliquots of $100 \mathrm{mg}$ ). The detection limits for the considered elements were: $0.2 \mu \mathrm{g} \mathrm{kg}^{-1}$ for $\mathrm{Co}, \mathrm{Cr}, \mathrm{Cu}$, and $\mathrm{Pb} ; 0.4 \mu \mathrm{g} \mathrm{kg}^{-1}$ for $\mathrm{Hg}$ and $\mathrm{Zn}$; $0.8 \mu \mathrm{g} \mathrm{kg}^{-1}$ for $\mathrm{Ni}$.

The extractable (available) amounts of $\mathrm{Cr}, \mathrm{Cu}, \mathrm{Ni}$, $\mathrm{Pb}$, and $\mathrm{Zn}$ were estimated by $0.05 \mathrm{~mol} \mathrm{~L}^{-1}$ EDTA extraction at $\mathrm{pH} 7$, with a $1: 10$ soil:solution ratio (Quevauviller et al., 1997) and the solutions were analysed by ICP-MS, Agilent 7500ce, Waldbronn, 
Germany. Extractable $\mathrm{Co}$ and $\mathrm{Hg}$ were not determined since a series of tests made on several samples gave always results below the respective detection limits.

\section{Biochemical analyses}

The microbial biomass $\mathrm{C}\left(\mathrm{C}_{\mathrm{mic}}\right)$ content was determined by the fumigation-extraction method of Vance et al. (1987), after 21 days of incubation at $25^{\circ} \mathrm{C}$ and at $50 \%$ of the sample total water holding capacity. During this incubation period, basal respiration was obtained by measuring the respired $\mathrm{CO}_{2}$ by gaschromatography (Blackmer \& Bremner, 1977). Basal respiration was expressed as the cumulative amount of $\mathrm{CO}_{2}-\mathrm{C}$ evolved during the incubation period $\left(\sum \mathrm{CO}_{2}-\right.$ $\mathrm{C})$. The specific microbial respiration, or metabolic quotient $\left(\mathrm{qCO}_{2}\right)$, expresses the $\mathrm{CO}_{2}-\mathrm{C}$ evolved per unit of microbial biomass $\mathrm{C}$ and time $\left(\mu \mathrm{g} \mathrm{CO}_{2}-\mathrm{C}\right.$ $\mathrm{mg}^{-1} \mathrm{C}_{\mathrm{mic}} \mathrm{h}^{-1}$ ) and was calculated according to Anderson \& Domsch (1993).

Alkaline and acid phosphatases activities were assayed according to Tabatabai (1994). Briefly, $1.00 \mathrm{~g}$ subsample at field moisture conditions was placed in a $50-\mathrm{ml}$ flask and added of $0.2 \mathrm{ml}$ of toluene, $4 \mathrm{ml}$ of Modified Universal Buffer solution (MUB) at $\mathrm{pH} 6.5$ for the assay of acid phosphatase or at $\mathrm{pH} 11$ for the assay of alkaline phosphatase, and $1 \mathrm{ml}$ of $0.05 \mathrm{M} p$ nitrophenyl phosphate solution. Once mixed the content, the stopped flask was placed in incubator at $37{ }^{\circ} \mathrm{C}$. After $1 \mathrm{~h}, 1 \mathrm{ml}$ of $0.5 \mathrm{M} \mathrm{CaCl}_{2}$ solution and $4 \mathrm{ml}$ of $0.5 \mathrm{M} \mathrm{NaOH}$ solution were added, and the content mixed for few seconds. The soil suspension was filtered through a Whatman 42 filter, and the yellow colour intensity of the filtrate measured against a control at $420 \mathrm{~nm}$ by a Varian Cary ${ }^{\circledR} 50 \mathrm{UV}-\mathrm{Vis}$ spectrophotometer (Victoria, Australia). The B-glucosidase activity was assessed by Eivazi \& Tabatabai (1988), using the analogue substrate para-nitrophenylß-D-glucopyranoside ( $p$-NPG). A subsample of $1.00 \mathrm{~g}$ at field moisture conditions was put into a screw-cap glass tube (three replicates per sample) and incubated for $1 \mathrm{~h}$ in a water bath at $37{ }^{\circ} \mathrm{C}$ with $4 \mathrm{ml}$ of $0.05 \mathrm{M}$ MUB at pH 6.0 and $1 \mathrm{ml}$ of $10 \mathrm{mM}$-NPG solution dissolved in the buffer. The reaction was stopped by adding $1 \mathrm{ml}$ of $0.5 \mathrm{M} \mathrm{CaCl}_{2}$ solution and $4 \mathrm{ml}$ of $0.2 \mathrm{M}$ tris(hydroxymethyl)aminomethane (tris) solution adjusted to $\mathrm{pH} 12$ with $\mathrm{NaOH}$. The mixture was centrifuged for $10 \mathrm{~min}$ at $1500 \mathrm{~g}$ and the absorbance measured at $410 \mathrm{~nm}$ by the Varian Cary ${ }^{\circledR} 50 \mathrm{UV}-\mathrm{V}$ is spectrophotometer. Values were corrected for a blank (substrate added immediately after the addition of $\mathrm{CaCl}_{2}$ and tris-NaOH) and for the adsorption of paranitrophenol $(p-\mathrm{NP})$ released in the soil (Vuorinen, 1993). Urease activity was assessed per Tabatabai (1994). A subsample of $2.00 \mathrm{~g}$ at field moisture conditions was put into a $50-\mathrm{mL}$ flask (three replicates) and incubated for $2 \mathrm{~h}$ in a water bath at $37{ }^{\circ} \mathrm{C}$ with $0.2 \mathrm{~mL}$ of toluene solution, $4 \mathrm{~mL}$ of $0.05 \mathrm{M}$ tris solution adjusted to $\mathrm{pH} 9$ with $\mathrm{H}_{2} \mathrm{SO}_{4}$, and $0.5 \mathrm{~mL}$ of $0.2 \mathrm{M}$ urea solution. The reaction was stopped by adding $35 \mathrm{~mL}$ of $2.5 \mathrm{M} \mathrm{KCl}$ plus $0.32 \mathrm{mM} \mathrm{Ag}_{2} \mathrm{SO}_{4}$ solution. Once the suspension was cooled, it was brought to $50 \mathrm{~mL}$ with the $\mathrm{KCl}-\mathrm{Ag}_{2} \mathrm{SO}_{4}$ solution. The ammonium released was measured on $20-\mathrm{mL}$ aliquot of the suspension with an ammonium selective electrode after the addition of $0.1 \mathrm{~mL}$ of $10 \mathrm{M} \mathrm{NaOH}$ solution. A control without urea was measured for each sample (Tabatabai, 1982).

Rationale for the proposed threshold of attention

As mentioned above, regulatory guidelines defining the soil limits for metal(loid)s often do not differentiate urban soils from other soil types, while limits for heavy metals contaminating urban soils would be useful especially for cities with a history of centuries or millennia during which human activities have introduced heavy metals in soil. Because of this, we propose the "threshold of attention" calculated as follows

$\mathrm{ToA}=M_{a}+1 / 2 S D$

where

ToA = threshold of attention for each element;

$M_{\mathrm{a}}=$ arithmetic mean of the total concentrations;

$S D=$ standard deviation .

Both $M_{\mathrm{a}}$ and SD were calculated at the city level and the choice to consider a half of the $S D(1 / 2 S D)$ was guided by the wish to bring out the hot spot soils where it is more impellent to intervene in order to mitigate or avoid potential environmental concerns. Practically, this threshold is mobile in time, meaning that, after recovery measures activated in some hot spots to reduce the heavy metal content, ToA may change and soils once under the threshold may then exceed it and require mitigating interventions. 
Data analysis

The physicochemical analyses were run in duplicate and the analytical mean was calculated. For each parameter, the analytical means of the three samples collected from each area were averaged to obtain the arithmetic mean and the standard deviation for each location $(n=3)$. The total concentrations of $\mathrm{Co}, \mathrm{Cr}$, $\mathrm{Cu}, \mathrm{Hg}, \mathrm{Ni}, \mathrm{Pb}$, and $\mathrm{Zn}$ in clay, silt, and sand separates, the extractable $\mathrm{Cr}, \mathrm{Cu}, \mathrm{Ni}, \mathrm{Pb}$, and $\mathrm{Zn}$, and all the biochemical analyses were run in duplicate on one of the three samples collected per location; for these analyses, we report the analytical mean of the sample.

\section{Results}

Soil physicochemical properties

The $\mathrm{pH}$ values of the urban soils of Ancona ranged from 7.1 to 7.6 , with an average value of $\approx 7.4$ (Table 2). In general, the particle-size distribution ranged from silty clay loam to clay loam, with a few soils showing a silty loam texture (Table 2 ). The active carbonate represents the finest and more reactive carbonaceous particles; its content ranged from 40 to $156 \mathrm{~g} \mathrm{~kg}^{-1}$ with an average value of $\approx 109 \mathrm{~g} \mathrm{~kg}^{-1}$, which was roughly one-third of the total carbonates (Table 2). One exception was the flowerbed soil of Torrette neighbourhood, where values of active carbonate were low but represented $\approx 60 \%$ of the total carbonates. The contents of TOC (from 20.7 to $51.5 \mathrm{~g} \mathrm{~kg}^{-1}$ ) and total $\mathrm{N}$ (from 0.9 to $5.9 \mathrm{~g} \mathrm{~kg}^{-1}$ ) gave $\mathrm{C} / \mathrm{N}$ ratios that, in 12 out of 18 locations, fell in the range 10-15 (Table 2). In the flowerbeds of the customs house of the Harbour and of Porta Pia, we obtained the lowest $\mathrm{C} / \mathrm{N}$ ratio values (around 9), while the highest value was 48 at the Palombella park. Available $P$ ranged from 6 to $202 \mathrm{mg} \mathrm{kg}^{-1}$ (Table 2), with an average value of $56 \mathrm{mg} \mathrm{kg}^{-1}$ and in 13 of the 18 locations the values were above the shortage limit of the method applied $\left(23 \mathrm{mg} \mathrm{kg}^{-1}\right)$. The content of exchangeable cations followed the order $\mathrm{Ca}>>$ $\mathrm{Mg}>\mathrm{K} \geq \mathrm{Na}$, typical of soils derived from calcareous parent materials (Table 2).

Many soils showed a mineralogical composition with calcite as the most represented mineral, followed by quartz, clay minerals, plagioclases, micas, kaolinite, and dolomite (Table 3). In some soils, small amounts of amphiboles, pyroxenes, primary chlorite, and serpentine (mainly antigorite) were also detected. The antigorite of these soils contained from 432 to $788 \mathrm{mg} \mathrm{kg}^{-1} \mathrm{Cr}$, and from 547 to $850 \mathrm{mg} \mathrm{kg}^{-1} \mathrm{Ni}$. Even though we cannot exclude the possibility that allochthonous materials were added to these soils, it is also true that antigorite is ubiquitous in amounts of $2-4 \%$ in a soil belt of the southern Po river delta that spans from the Adriatic coast to $10-15 \mathrm{~km}$ inland, often accompanied by small amounts of amphiboles and chlorite (Cocco et al., 2007). Instead, pyroxenes have rarely been detected in the same soils of this inland belt, but they were observed in three flowerbeds: the two at the harbour and one from Viale della Vittoria.

Heavy metals in the city soils

Over the 18 locations, five out of the seven elements considered $(\mathrm{Co}, \mathrm{Cr}, \mathrm{Cu}, \mathrm{Hg}$, and $\mathrm{Ni}$ ) showed $\mathrm{ToA}$ similar or lower than the limits of the Italian legislation, while for $\mathrm{Pb}$ and $\mathrm{Zn}$ ToA was higher (Table 4). Each heavy metal exceeded its ToA in three to five locations. For example, $\mathrm{Cu}$ and $\mathrm{Zn}$ showed concentrations higher than their ToA in three locations, Co overcame ToA in four locations, while $\mathrm{Cr}, \mathrm{Pb}, \mathrm{Ni}$, and $\mathrm{Hg}$ exceeded their ToA in five locations. As a whole, in nine out of 18 locations ToAs were exceeded by two to six heavy metals. In details, the flowerbed close to the custom house at the Harbour was the worst location, with six metals above $\mathrm{ToA}(\mathrm{Cr}, \mathrm{Cu}, \mathrm{Hg}, \mathrm{Ni}$, $\mathrm{Pb}$, and $\mathrm{Zn}$ ) and both $\mathrm{Pb}$ and $\mathrm{Zn}$ with the highest concentrations found in the city soils (317 and $592 \mathrm{mg} \mathrm{kg}^{-1}$, respectively). In four sites, three heavy metals exceeded their ToA: the exciding elements were $\mathrm{Hg}, \mathrm{Ni}$, and $\mathrm{Pb}$ in the Cavour square flowerbed; $\mathrm{Co}, \mathrm{Cr}$, and $\mathrm{Ni}$ in the Passetto and Posatora flowerbeds; $\mathrm{Cu}, \mathrm{Pb}$, and $\mathrm{Zn}$ in the Corso Carlo Alberto private gardens. In other four locations, two elements were higher than ToA: $\mathrm{Cu}$ and $\mathrm{Zn}$ in the recreational area of Palombella Park; $\mathrm{Hg}$ and $\mathrm{Pb}$ in the Cathedral and Porta Pia flowerbeds; Co and Ni in the flowerbed close to the Trajan arch at the Harbour. Finally, in four locations one heavy metal overcame ToA: $\mathrm{Cr}$ in the recreational area of Altavilla park and the flowerbed at Torrette, $\mathrm{Hg}$ in the recreational area of Cardeto park, and Co in the recreational area of Cittadella park.

Table 5 shows the total content of the seven elements in each soil separate. In general, $\mathrm{Cr}, \mathrm{Cu}, \mathrm{Hg}$, 


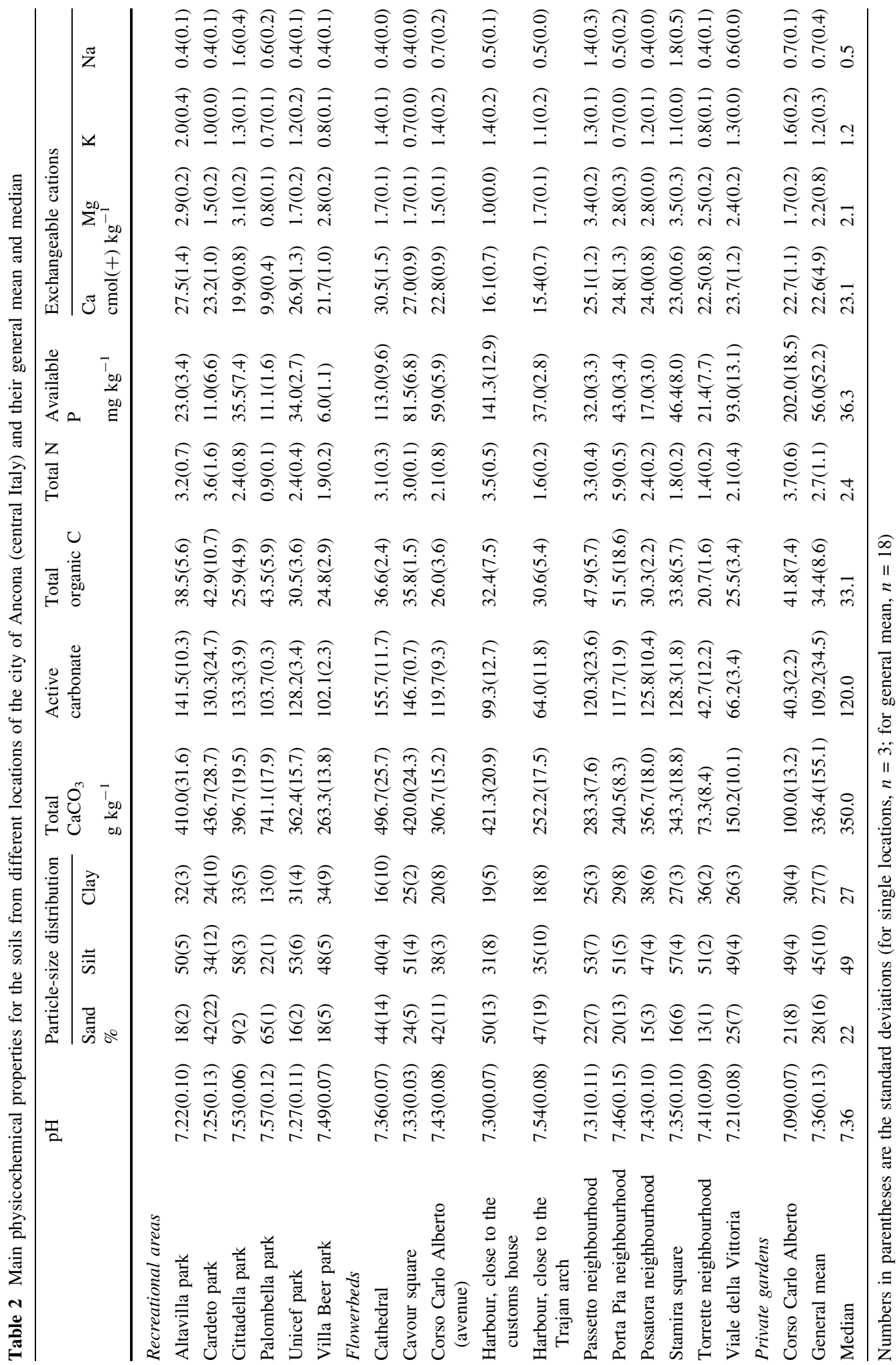




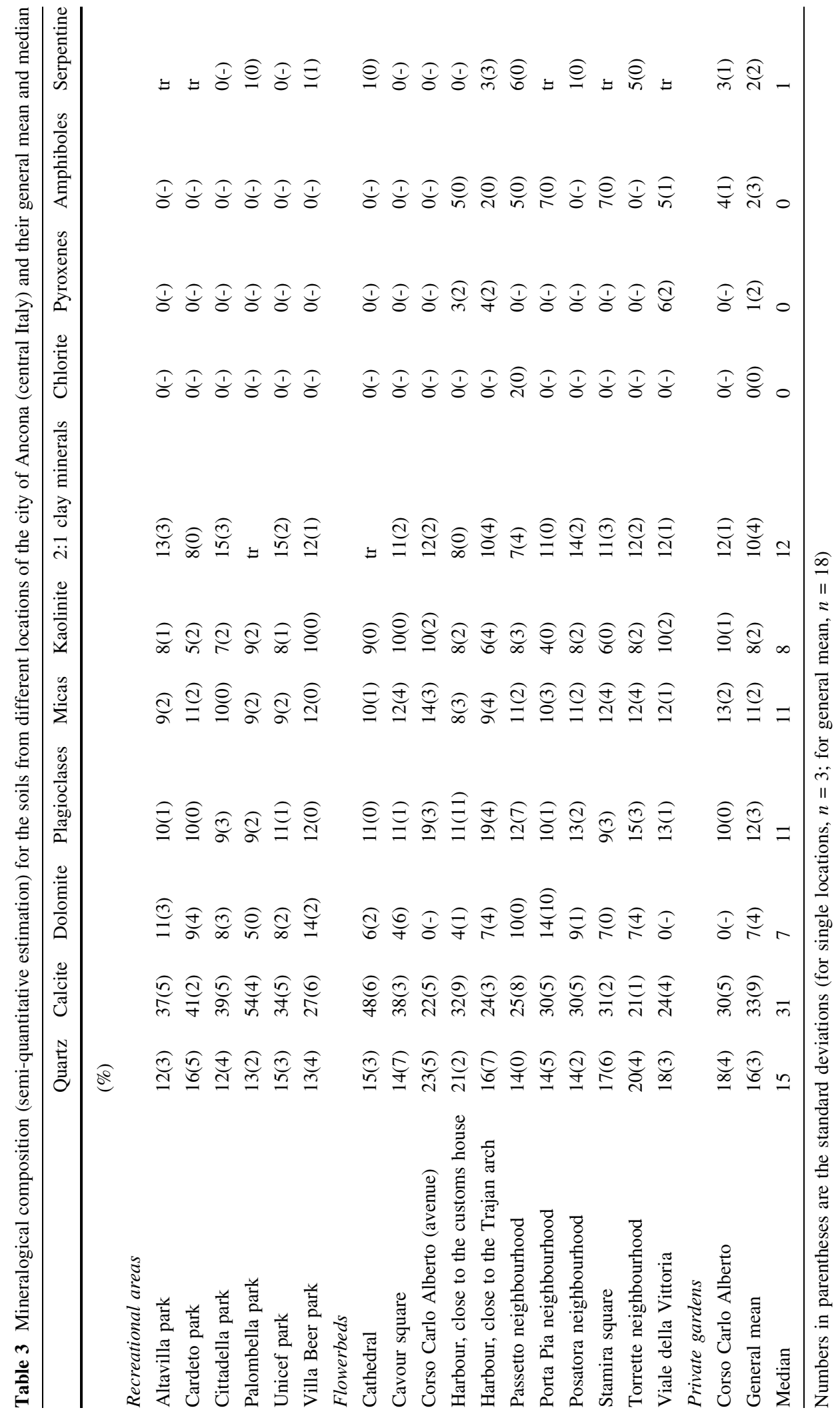


Table 4 Total concentrations of heavy metals for the soils from different locations of the city of Ancona (central Italy) and their general mean, median, and threshold of attention

\begin{tabular}{|c|c|c|c|c|c|c|c|}
\hline & $\begin{array}{l}\mathrm{Co} \\
\mathrm{mg} \mathrm{kg}^{-1}\end{array}$ & $\mathrm{Cr}$ & $\mathrm{Cu}$ & $\mathrm{Hg}$ & $\mathrm{Ni}$ & $\mathrm{Pb}$ & $\mathrm{Zn}$ \\
\hline \multicolumn{8}{|l|}{ Recreational areas } \\
\hline Altavilla park & $18(0)$ & $87(10)$ & $48(24)$ & $0.11(0.05)^{*}$ & $49(7)$ & $66(12)$ & $187(29) \dagger$ \\
\hline Cardeto park & $16(2)$ & $28(8)$ & $28(6)$ & $0.86(0.23)^{*}$ & $45(12)$ & $52(8)$ & $105(12)$ \\
\hline Cittadella park & $20(1) \dagger$ & $39(4)^{*}$ & $37(13)$ & $0.25(0.04)$ & $50(10)$ & $87(21)$ & $124(38)^{*}$ \\
\hline Palombella park & $15(2)$ & $31(4)$ & $282(38) * \dagger$ & $0.02(0.01)^{*}$ & $40(15)$ & $89(11)$ & $280(-)^{* * \dagger}$ \\
\hline Unicef park & $19(2)$ & $45(7)$ & $33(8)$ & $0.14(0.03)$ & $53(27)^{*}$ & $42(9)$ & $76(7)$ \\
\hline Villa Beer park & $16(2)$ & $35(2)$ & $21(13)$ & $0.04(0.03)$ & 43(17) & $25(4)$ & $67(25)$ \\
\hline \multicolumn{8}{|l|}{ Flowerbeds } \\
\hline Cathedral & $16(0)$ & 21(3) & $41(8)$ & $0.93(0.31)^{*}$ & $31(21)$ & $192(48) * \dagger$ & $268(47)^{* \dagger}$ \\
\hline Cavour square & $19(1)$ & $46(4)$ & $56(2)$ & $0.50(0.19)$ & $59(3)$ & $173(7) \dagger$ & $191(27) \dagger$ \\
\hline Corso Carlo Alberto (avenue) & $17(1)$ & $48(2)$ & $57(46)$ & $0.03(0.02)^{*}$ & $50(1)$ & $70(65)$ & $212(150) \dagger$ \\
\hline Harbour, close to the customs house & $19(1)$ & 58(7) & $141(24) \dagger$ & $0.88(0.81)$ & $\mathbf{5 8}(4)$ & $317(51) \dagger$ & $592(124) \dagger$ \\
\hline Harbour, close to the Trajan arch & $23(2)^{*} \dagger$ & $51(8)$ & $36(-)^{* *}$ & $0.22(0.09)^{*}$ & $77(22)$ & $46(-)^{* *}$ & $118(36)$ \\
\hline Passetto neighbourhood & $22(0) \dagger$ & $56(-)^{* *}$ & $42(2)$ & $0.16(0.04)$ & $\mathbf{5 8}(17)$ & $62(15)^{*}$ & $176(15)^{* \dagger}$ \\
\hline Porta Pia neighbourhood & $19(1)$ & $37(3)^{*}$ & $55(17)$ & $0.45(0.09)$ & $45(19)$ & $221(68)^{* \dagger}$ & $255(28) \dagger$ \\
\hline Posatora neighbourhood & $20(2) \dagger$ & $53(6)$ & $35(9)$ & $0.05(0.03)^{*}$ & $56(11)$ & $33(-)^{* *}$ & $83(20)$ \\
\hline Stamira square & $18(2)$ & $38(2)$ & $38(4)$ & $0.12(0.04)$ & $53(2)$ & $43(3)$ & $141(28)$ \\
\hline Torrette neighbourhood & $17(1)$ & $58(5)$ & $31(1)$ & $0.07(0.03)^{*}$ & $51(7)^{*}$ & $31(5)$ & $75(5)$ \\
\hline Viale della Vittoria & $16(2)$ & $46(13)$ & $42(16)$ & $0.06(0.03)$ & $50(6)$ & $46(11)$ & $137(42)$ \\
\hline \multicolumn{8}{|l|}{ Private gardens } \\
\hline Corso Carlo Alberto & $16(1)$ & $44(8)$ & $127(18) \dagger$ & $0.21(0.06)$ & $48(8)$ & $159(49) \dagger$ & $496(159) \dagger$ \\
\hline General mean & $18.1(2.2)$ & $45.6(14.6)$ & $63.9(63.1)$ & $0.28(0.31)$ & $50.9(9.5)$ & $97.4(81.3)$ & 199.1(143.0) \\
\hline Median & 18.0 & 45.5 & 41.5 & 0.15 & 50.0 & 64.0 & 158.5 \\
\hline $\begin{array}{l}\text { Proposed threshold of attention (general } \\
\text { mean }+1 / 2 \text { standard deviation) }\end{array}$ & 19.2 & 52.9 & 95.5 & 0.44 & 55.7 & 138.1 & 270.6 \\
\hline
\end{tabular}

Numbers in parentheses are the standard deviations (for single locations, $n=3$; for general mean, $n=18$ ). Locations in bold are those with one or more heavy metals overcoming the threshold of attention; the values in bold are those overcoming the threshold of attention for the respective heavy metal

$* n=2$

$* *_{\mathrm{n}}=1$

${ }^{\dagger}$ Concentrations exceeding the limit for residential areas according to the Italian law, which are: $20 \mathrm{mg} \mathrm{kg}^{-1} \mathrm{for} \mathrm{Co}_{150 \mathrm{mg} \mathrm{kg}}{ }^{-1}$ for $\mathrm{Cr} ; 120 \mathrm{mg} \mathrm{kg}^{-1}$ for $\mathrm{Cu} ; 1 \mathrm{mg} \mathrm{kg}^{-1}$ for $\mathrm{Hg} ; 120 \mathrm{mg} \mathrm{kg}^{-1}$ for Ni; $100 \mathrm{mg} \mathrm{kg}^{-1}$ for Pb; $150 \mathrm{mg} \mathrm{kg}^{-1}$ for Zn (Gazzetta Ufficiale No. 293, 15 December 1999)

$\mathrm{Ni}$, and $\mathrm{Zn}$ displayed the highest concentrations in the clay (or silt) fraction, while $\mathrm{Pb}$ often showed the highest concentrations in the sand. However, in the five locations where $\mathrm{Pb}$ exceeded $\mathrm{ToA}$, it showed the highest value in the clay. Cobalt was rather evenly distributed among the fractions. If calculated in relation to the proportion of the particle-size fractions (Table S1 of Supplementary Materials), on average, $\mathrm{Cr}$ and $\mathrm{Hg}$ of the clay contributed nearly $50 \%$ to the soil total concentration, whereas for $\mathrm{Ni}$ and $\mathrm{Zn}$ both clay and silt contributed for $\approx 40 \%$. In the case of Co, $\mathrm{Cu}$, and $\mathrm{Pb}$ the silt fraction was the main contributor to the total content. Since it is usually expected that the recently added metals concentrate in the clay (Ugwu \& Igbokwe, 2019), our observations indicated that a great part of the considered elements has lithogenic or ancient sources. 


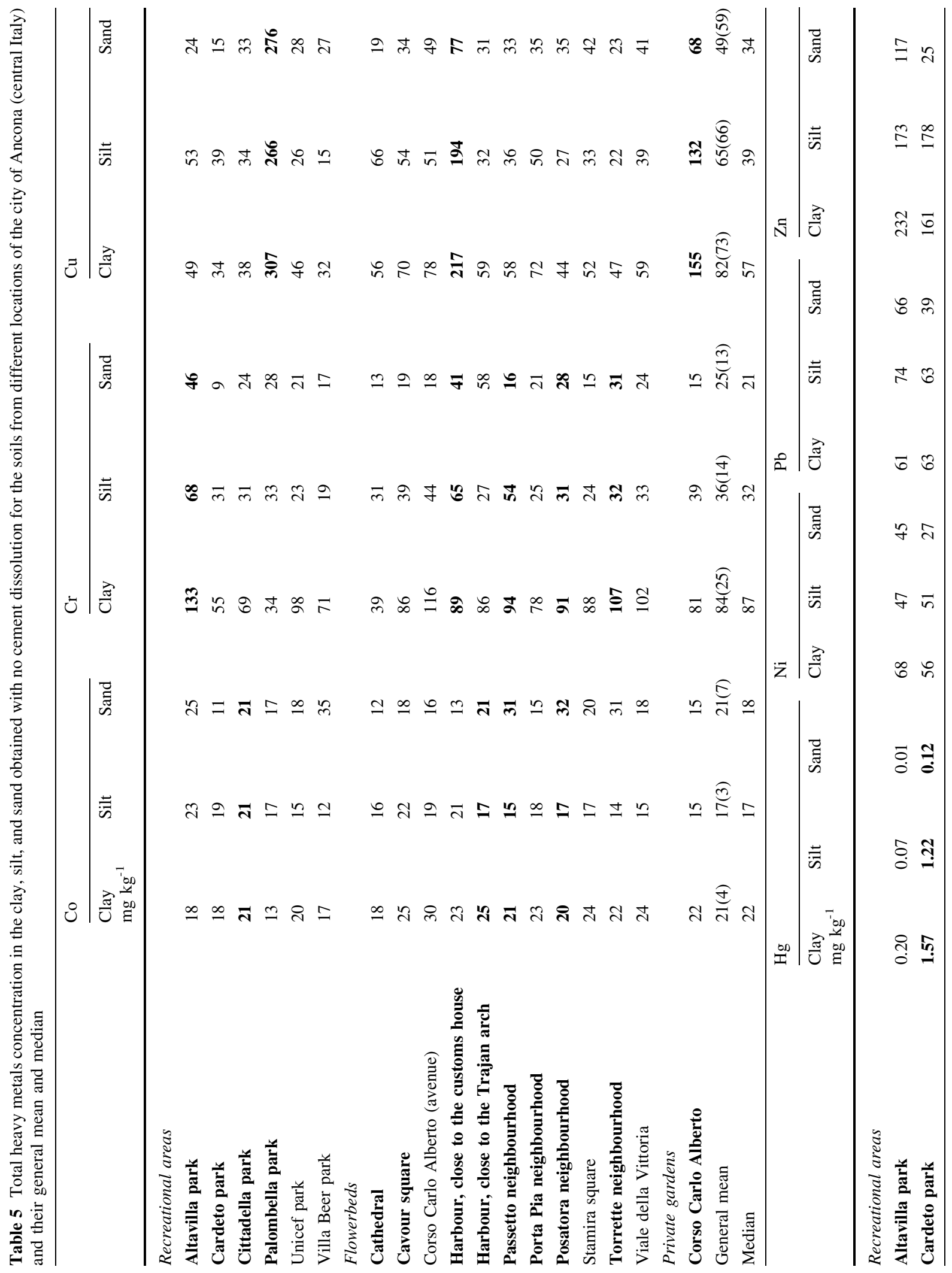




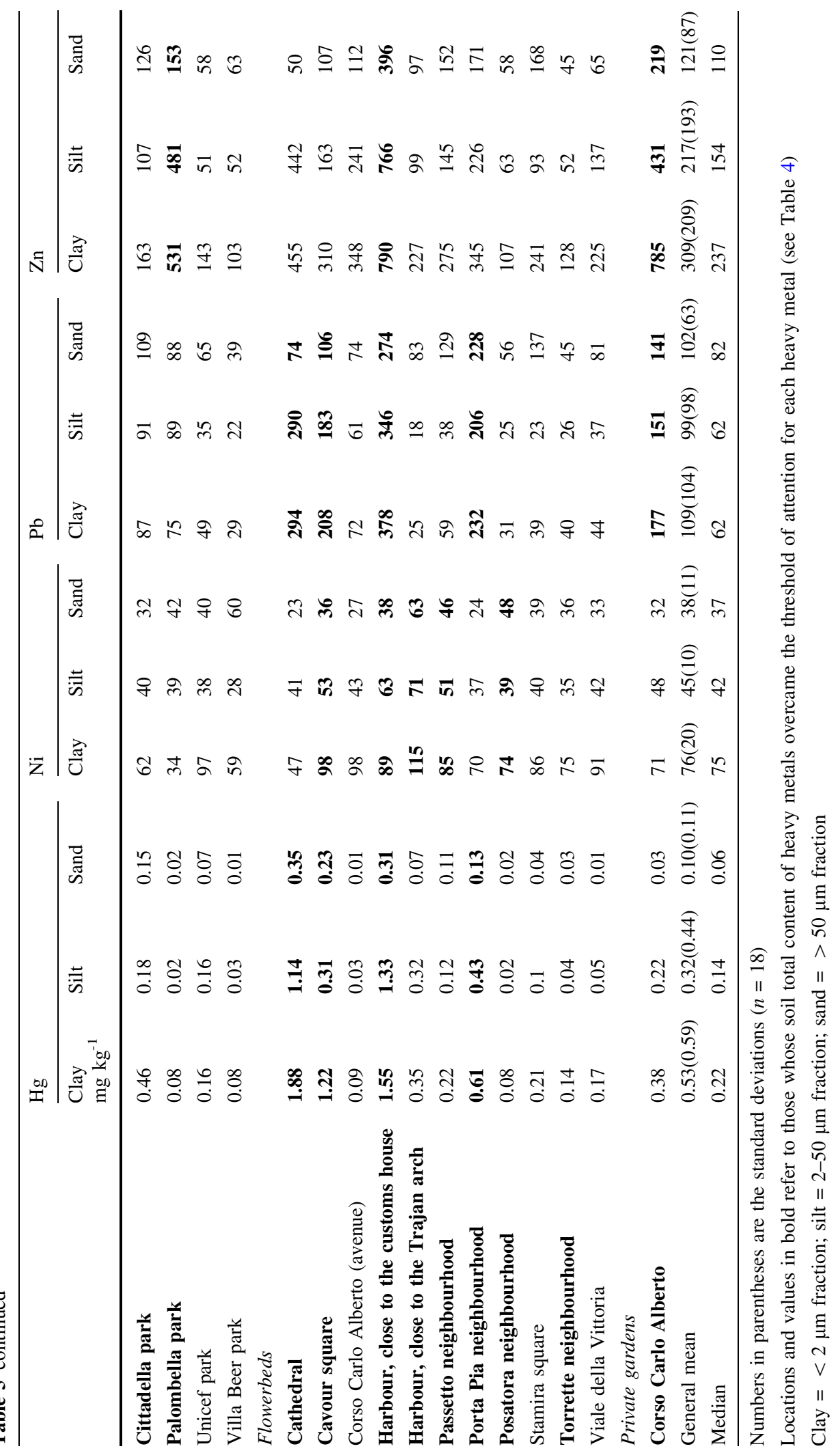


The amounts of extractable $\mathrm{Cr}$ were always below the detection limit of the method $\left(25 \mu \mathrm{g} \mathrm{kg}^{-1}\right)$, while the other heavy metals showed the following order of extraction: $\mathrm{Zn}>\mathrm{Pb}>\mathrm{Cu}>\mathrm{Ni}$ (Table 6), and the general percentage of extractable relative to the total element content ranged from $\approx 0 \%$ for $\mathrm{Cr}$ to $\approx 28 \%$ for $\mathrm{Pb}$ (Table 6). The highest percentages of extractable $\mathrm{Cu}$ and $\mathrm{Pb}$ were found in the flowerbed of Viale della Vittoria, whose soil was replaced two years before the sampling; the highest proportion of extractable Ni was obtained for the recreational area of the Altavilla park, and that of $\mathrm{Zn}$ for the flowerbed of Stamira square.

\section{Soil biological and biochemical properties}

The $\mathrm{C}_{\text {mic }}$ content was the lowest in the recreational area of Palombella park, and the highest in the flowerbed of Porta Pia (Table 7). For this latter location, we also obtained the lowest amount of respired $\mathrm{CO}_{2}$ (399 $\mu \mathrm{g} \mathrm{CO}_{2}-\mathrm{C} \mathrm{g}^{-1}$ soil). Because of the combination of the highest $\mathrm{C}_{\text {mic }}$ content and the lowest $\sum \mathrm{CO}_{2}-\mathrm{C}$, the flowerbed of Porta Pia showed the lowest $\mathrm{qCO}_{2}$ value $\left(0.6 \mu \mathrm{g} \mathrm{CO}_{2}-\mathrm{C} \mathrm{mg}^{-1} \mathrm{C}_{\text {mic }} \mathrm{h}^{-1}\right)$. For all the soils, we obtained a general $\mathrm{qCO}_{2}$ mean value of 3.7, with a maximum value of 10.5 at Palombella park. This location showed also the lowest values of the four enzyme activities (Table 7), while the flowerbed of Porta Pia displayed the highest values of alkaline and acid phosphatase activities. The highest B-glucosidase and urease activities were measured for the Cathedral flowerbed.

\section{Discussion}

Physicochemical properties of the city soils in comparison with the surrounding soils

The $\mathrm{pH}$ range of the urban soils (7.1-7.6) was slightly lower than that of the cultivated soils surrounding the city (Table S2 of Supplementary Materials). This indicates that, rather than to be added of municipal demolition waste, a common practice in urban context that has an alkalinizing effect (Alexandrovskaya \& Alexandrovskiy, 2000; Biasioli et al., 2006), the Ancona's urban soils were added of materials that slightly reduced alkalinity; $\mathrm{NH}_{4}$-based fertilizers and organic amendments could have been responsible for this. All the soils showed a large content of clay-size particles. This could raise some concern since soils with fine texture may represent a repository of inorganic and organic particles (partly originated by anthropogenic activities) contributing through wind blasts to increase air levels of PM2.5, which are easily inhaled by humans with deep penetration into the lungs (e.g. Atzei et al., 2019; Unda-Calvo et al., 2019; Wu et al., 2007). The soil textures of the Ancona urban soils appeared to be mostly inherited from the parental material of this area, represented by carbonaceous marine and fluvio-marine sediments, and are similar to those of the rural soils surrounding the city (Table S2 of Supplementary Materials). However, since the substances most involved in heavy metals (selective) adsorption are colloids like clay minerals belonging to the smectites and vermiculites groups (e.g. Gupta \& Bhattacharyya, 2012; Malandrino et al., 2006; Otunola \& Ololade, 2020), Fe-, Al-, and Mn-oxyhydroxides (e.g. Fialova 2014; Ni et al., 2009; Shi et al., 2021), and organic matter (e.g. Bradl, 2004; KwiatkowskaMalina, 2018), the high soil clay content can be considered as a positive factor being able to reduce the bioavailability of heavy metals. Since the windblowing of the soil fine fraction may contain colloids with adsorbed metals, a proper management of the urban soils aimed at avoiding wind erosion can help reducing the possibility for humans to assimilate heavy metals by inhalation or ingestion (Abrahams, 2002; Higgs et al., 1999; Lasat, 2001; Padoan et al., 2017). Also the presence of active carbonate is a positive aspect because of its capability to induce precipitation/immobilization of many heavy metals (e.g. Huang et al., 2016; Wuana \& Okieimen, 2011). The contents of TOC and total N were fairly higher with respect to the highest contents of the rural soils of the surroundings (Table S2 of Supplementary Materials) and were ascribed to the addition of fertilizers and organic amendments. The alteration of the applied organic amendments, with production of acidity, was probably the reason of the generalized lower $\mathrm{pH}$ of the urban soils. In addition, other than complexing heavy metals, organic matter is also involved in the formation of soil structure, so creating aggregates sufficiently heavy to reduce wind-blowing. In the case of parks, the soil appeared to be the remainders of in situ soils after they were scalped, reworked, or deeply ploughed. Therefore, with respect to the rural soils of the surroundings, the urban soils showed similar 


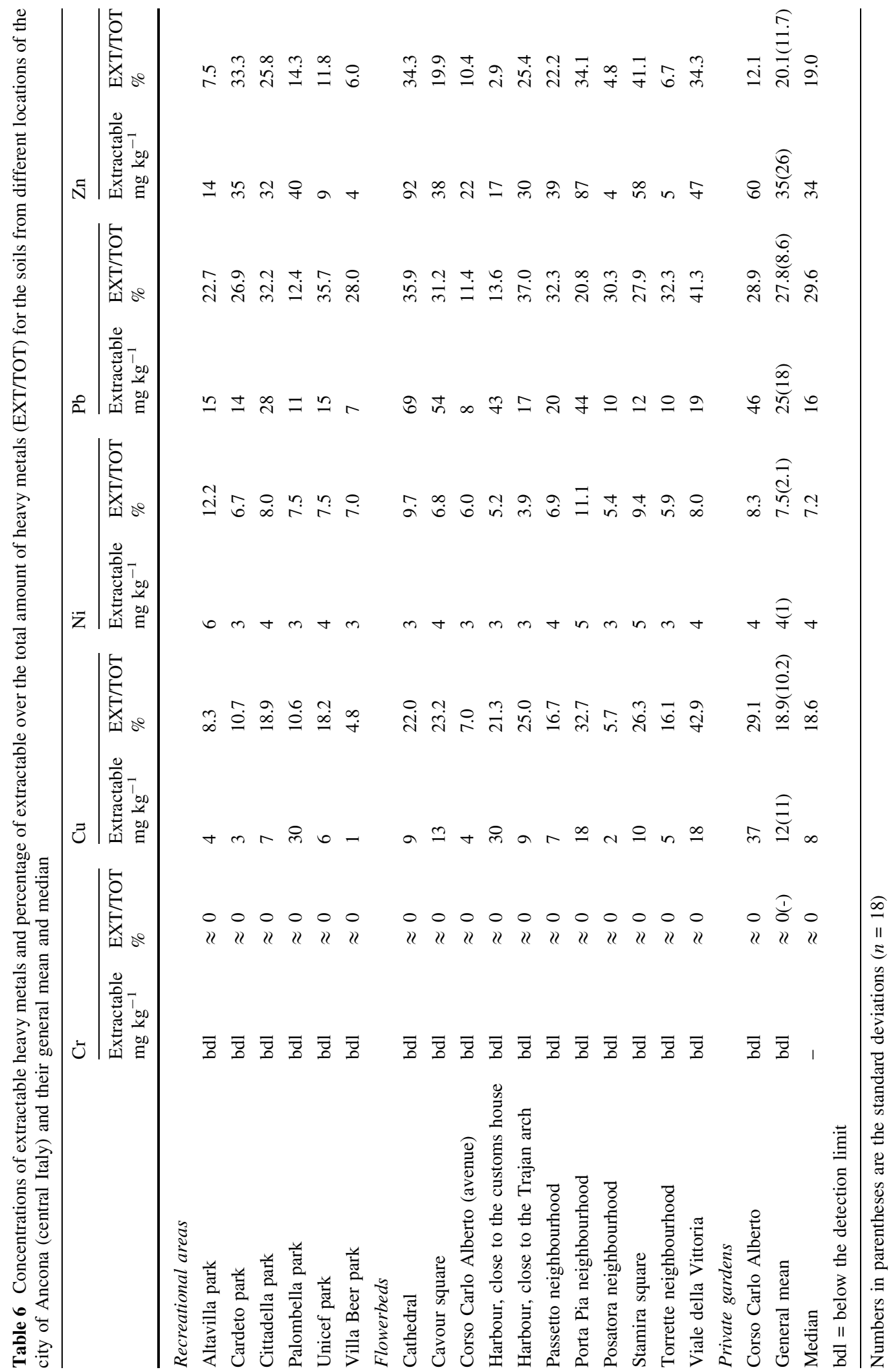


Table 7 Microbial biomass $\mathrm{C}$ content $\left(\mathrm{C}_{\text {mic }}\right)$, cumulative amount of $\mathrm{CO}_{2}$ evolved during 21 days of incubation $\left(\sum \mathrm{CO}_{2}-\right.$ C), metabolic quotient $\left(\mathrm{qCO}_{2}\right)$, and activities of alkaline phosphatase, acid phosphatase, ß-glucosidase, and urease for the soils from different locations of the city of Ancona (central Italy) and their general mean and median

\begin{tabular}{|c|c|c|c|c|c|c|c|}
\hline & $\begin{array}{l}\mathrm{C}_{\text {mic }} \\
\mu \mathrm{g} \mathrm{C} \mathrm{g}^{-1} \\
\text { soil }\end{array}$ & $\begin{array}{l}\sum \mathrm{CO}_{2}-\mathrm{C} \\
\mu \mathrm{g} \mathrm{CO}_{2}-\mathrm{C} \\
\mathrm{g}^{-1} \text { soil }\end{array}$ & $\begin{array}{l}\mathrm{qCO}_{2} \\
\mu \mathrm{CO}_{2}-\mathrm{C} \mathrm{mg}^{-1} \\
\mathrm{C}_{\text {mic }} \mathrm{h}^{-1}\end{array}$ & $\begin{array}{l}\text { Alkaline } \\
\text { phosphatase } \\
\mu \mathrm{g} p-\mathrm{NP} \mathrm{g}^{-1} \mathrm{~h}\end{array}$ & $\begin{array}{l}\text { Acid } \\
\text { phosphatase }\end{array}$ & $\begin{array}{l}\text { ß- } \\
\text { glucosidase }\end{array}$ & $\begin{array}{l}\text { Urease } \\
\mu \text { mol urease } \\
\mathrm{g}^{-1} \mathrm{~h}^{-1}\end{array}$ \\
\hline \multicolumn{8}{|l|}{ Recreational areas } \\
\hline Altavilla park & 328 & 577 & 3.5 & 13874 & 623 & 9569 & 215 \\
\hline Cardeto park & 228 & 644 & 5.6 & 11067 & 401 & 5136 & 102 \\
\hline Cittadella park & 626 & 466 & 1.5 & 10408 & 362 & 3313 & 52 \\
\hline Palombella park & 96 & 508 & 10.5 & 6330 & 77 & 1229 & 52 \\
\hline Unicef park & 473 & 489 & 2.1 & 13759 & 618 & 9835 & 223 \\
\hline Villa Beer park & 136 & 474 & 6.9 & 12231 & 429 & 4683 & 98 \\
\hline \multicolumn{8}{|l|}{ Flowerbeds } \\
\hline Cathedral & 810 & 514 & 1.3 & 15578 & 780 & 10884 & 337 \\
\hline Cavour square & 428 & 605 & 2.8 & 12106 & 513 & 7461 & 188 \\
\hline $\begin{array}{l}\text { Corso Carlo Alberto } \\
\text { (avenue) }\end{array}$ & 139 & 474 & 6.8 & 9668 & 412 & 3525 & 114 \\
\hline $\begin{array}{l}\text { Harbour, close to the } \\
\text { customs house }\end{array}$ & 308 & 566 & 3.6 & 12004 & 540 & nd & nd \\
\hline $\begin{array}{l}\text { Harbour, close to the } \\
\text { Trajan arch }\end{array}$ & nd & nd & nd & nd & nd & nd & nd \\
\hline Passetto neighbourhood & 529 & 938 & 3.5 & 17780 & 684 & 8725 & 285 \\
\hline $\begin{array}{l}\text { Porta Pia } \\
\text { neighbourhood }\end{array}$ & 1229 & 399 & 0.6 & 19840 & 1703 & 4306 & 92 \\
\hline Posatora neighbourhood & 488 & 453 & 1.8 & 14117 & 715 & 8907 & 256 \\
\hline Stamira square & nd & nd & nd & nd & nd & nd & nd \\
\hline Torrette neighbourhood & 450 & 502 & 2.2 & 13438 & 770 & 9320 & 282 \\
\hline Viale della Vittoria & 416 & 744 & 3.5 & 12353 & 671 & 6964 & 257 \\
\hline \multicolumn{8}{|l|}{ Private gardens } \\
\hline Corso Carlo Alberto & 259 & 458 & 3.5 & 11693 & 342 & 7012 & 197 \\
\hline General mean & $434(285)$ & $551(134)$ & $3.7(2.6)$ & $12890(3156)$ & $603(348)$ & $6725(2877)$ & $183(92)$ \\
\hline Median & 422 & 505 & 3.5 & 12292 & 579 & 7012 & 197 \\
\hline
\end{tabular}

Numbers in parentheses are the standard deviations $\left(n=16\right.$ for $\mathrm{C}_{\mathrm{mic}}, \sum \mathrm{CO}_{2}-\mathrm{C}, \mathrm{qCO}_{2}$, alkaline phosphatase, and acid phosphatase; $n=15$ for B-glucosidase and urease)

nd $=$ Not determined

physicochemical and mineralogical properties (Tables S2 and S3 of Supplementary Materials), with higher contents of TOC, total $N$, and available $P$ because of the addition of fertilizers and amendments used for green maintenance. Hence, it appears that the urban soils were not massively added of allochthonous earthy materials, unless these latter came from the surroundings. However, in three flowerbeds (two at the Harbour and that of Viale della
Vittoria) small amounts of allochthonous materials containing pyroxenes were probably added.

\subsection{Total concentration and distribution of heavy metals among the particle-size fractions}

ToA takes into consideration the mean condition of the city soils, where especially $\mathrm{Pb}$ and $\mathrm{Zn}$ have been accumulated with time. Then, ToA has also allowed us 
individuating nine soils where a multi-elemental accumulation occurred. In all the soils where heavy metals exceeded $T o A$, they were more abundant in the clay and, in many cases, in the silt too. This is in agreement with many authors (e.g. Acosta et al., 2009; Ajmone-Marsan et al., 2008; Gong et al., 2014; Liu et al., 2018; Yutong et al., 2016), who found that in the urban soils the fraction $<50 \mu \mathrm{m}$ was the most involved in heavy metal pollution. This fact farther increases the risk that heavy metals can be inhaled by people (e.g. Acosta et al., 2009; Sah et al., 2019). However, in the soils where $\mathrm{Pb}$ did not exceed its $T o A$, sand was the $\mathrm{Pb}$ richest fraction. Since $\mathrm{Pb}$ is a frequent isomorphic substitute of $\mathrm{Ca}$ in carbonaceous rock forming environments (e.g. Cheng et al., 2018; Haldar \& Tišljar, 2014; Kumpiene et al., 2008) and these soils contain calcite, we ascribed the relative abundance of $\mathrm{Pb}$ in the sand fraction to lithogenic origin (e.g. Acosta et al., 2009; Ajmone-Marsan et al., 2008). For the other six heavy metals, their accumulation in the silt and clay fractions was attributed to their adsorption on clay minerals and Fe-, Al-, and Mn-oxyhydroxides, and to the formation of complexes with humic substances (e.g. Dube et al., 2001; Groenenberg \& Lofts, 2014; Peng et al., 2018).

Among the nine soils with two or more metals exceeding the proposed ToA, in the flowerbed close to the custom house at the Harbour and in all the others with $\mathrm{Pb}$ over $\mathrm{ToA}$, clay (and often silt) showed the highest $\mathrm{Pb}$ contents, indicating that this heavy metal had an additional source other than lithology, probably represented by the past traffic of motor vehicles. The same is probably true for $\mathrm{Zn}$, since railway tracks, services, and junctions have been recognized to be $\mathrm{Zn}$ sources for the soils in the vicinity of these facilities in many parts of the World (e.g. Adamu et al., 2017; Akoto et al., 2008; Wiłkomirski et al., 2011; Zhang et al., 2012). For the other four heavy metals $(\mathrm{Cr}, \mathrm{Cu}$, $\mathrm{Ni}$, and $\mathrm{Hg}$ ), being sources like mining, industrial activities, and use of fertilizers and pesticides (e.g. Manta et al., 2002; Rodrigues et al., 2006; Wei \& Yang, 2010; Xueqiu et al., 2020) impossible to invoke for the city of Ancona, we suspect they came from the strong trade activities, fishery, the movement of more than 1.5 million tourists the harbour experiences yearly, but also from metallurgy, construction, and other human activities that succeeded since the foundation of the city.
In the four locations affected by high content of three heavy metals, when contaminants are represented by $\mathrm{Pb}$ and $\mathrm{Zn}$, since we did not take into consideration atmospheric deposition and irrigation water as possible sources, their excessive content was ascribed to the already mentioned vehicular traffic and railway, respectively. Thus, particular is the case of the flowerbeds of Passetto and Posatora, which are at the extreme east and west of the city, respectively ( $\approx 4 \mathrm{~km}$ of distance one from the other) but were contaminated by the same heavy metals: $\mathrm{Co}, \mathrm{Cr}$, and Ni. A certain amount of $\mathrm{Cr}$ and $\mathrm{Ni}$ could come from antigorite, which formed $6 \%$ of Passetto and $1 \%$ of Posatora soils. The antigorite in the Passetto soil contained $\quad 632 \pm 21 \mathrm{mg} \mathrm{kg}^{-1} \quad \mathrm{Cr} \quad$ and $711 \pm 16 \mathrm{mg} \mathrm{kg}^{-1} \mathrm{Ni}$, while that in the Posatora soil comprised $553 \pm 23 \mathrm{mg} \mathrm{kg}^{-1} \quad \mathrm{Cr} \quad$ and $634 \pm 24 \mathrm{mg} \mathrm{kg}^{-1} \mathrm{Ni}$. By considering the antigorite content, the amounts of $\mathrm{Cr}$ and $\mathrm{Ni}$ of mineral origin accounted for $\approx 38 \mathrm{mg} \mathrm{kg}^{-1} \mathrm{Cr}$ and $43 \mathrm{mg} \mathrm{kg}^{-1} \mathrm{Ni}$ in the Passetto soil, and for $\approx 6 \mathrm{mg} \mathrm{kg}^{-1} \mathrm{Cr}$ and $\mathrm{Ni}$ in the Posatora soil. Regarding the source of $\mathrm{Cr}$ and $\mathrm{Ni}$ exceeding the antigorite contribution in these two, but also in the other investigated soils depending on the relative antigorite content (ranging from $\approx 2.5$ to $\approx 31 \mathrm{mg} \mathrm{kg}^{-1}$ for $\mathrm{Cr}$ and from $\approx 4$ to $\approx 34 \mathrm{mg} \mathrm{kg}^{-1}$ for $\mathrm{Ni}$ ), we do not offer explanation except for the diffuse source of pollution typical of historical cities where all human activities succeeded with time (e.g. Christoforidis \& Stamatis, 2009; Luo et al., 2015; Tume et al., 2018).

Among the locations with two heavy metals overcoming ToA, particular is the case of the Palombella park, which resulted contaminated by $\mathrm{Cu}$ and $\mathrm{Zn}$, with the highest content of total $\mathrm{Cu}$ $\left(282 \mathrm{mg} \mathrm{kg}^{-1}\right)$. This park is close to a nowadays dismissed brick kiln, and this type of industrial activity has been assessed to be the source of heavy metals like $\mathrm{Cu}, \mathrm{Pb}$, and $\mathrm{Zn}$ that accumulate in the soils surrounding the factory (e.g. Achakzai et al., 2015; Begum et al., 2015; Bisht \& Neupane, 2015; Ishaq et al., 2010; Ismail et al., 2012). Because of this, we attributed most of the contents of $\mathrm{Cu}$ and $\mathrm{Zn}$ found in the soil of Palombella park to the activity of the dismissed brick kiln. For all the other situations with one of more heavy metals overcoming ToA, we considered the relatively high level of contamination was due to all human activities that in cities funded century or millennia ago may leave trace into the soil, or to 
accidental contaminations typical of cities with strong trade activities combined with vehicular, railway, and naval traffic. This, in turn, represents the serious problem to define a fixed reference threshold for historical cities.

\section{Extractability of heavy metals in the city soils}

Soil functionalities are compromised when the availability of heavy metals is sufficiently high to interfere with soil biological activities (e.g. Khan et al., 2007; Wang et al., 2018; Xian et al., 2015). Because of this, many authors have determined the availability of heavy metals to assess the thresholds over which soil functions might be compromised (e.g. Basta et al., 2005; Madrid et al. 2008; Yutong et al., 2016). In the soils of Ancona, the percentage of availability over the total content of heavy metal followed the order $\mathrm{Pb}>\mathrm{Zn} \approx \mathrm{Cu}>\mathrm{Ni}>\mathrm{Cr}$. In general, when soil has sub-alkaline $\mathrm{pH}$, the chemical availability of heavy metals is small and, when they are introduced into the soil or released by weathering of the mineral lattices, they are immobilized as hydroxides or co-precipitate with secondary carbonates (e.g. Huang et al., 2016; Kabata-Pendias \& Pendias, 2001). Then, when in cationic form, heavy metals can be adsorbed by clay minerals and carbonates, or complexed by humic substances, especially at sub-alkaline $\mathrm{pH}$ (e.g. Chuan et al., 1996; Peganova \& Edler, 2004), so slowing down their availability. However, the amount of extractable $\mathrm{Cu}, \mathrm{Ni}, \mathrm{Pb}$, and $\mathrm{Zn}$ of our soils gave not significant tendency lines when related to total carbonates, active carbonate, TOC, and clay minerals (2:1 clay minerals plus kaolinite) content (Fig. S1 of Supplementary Materials). Therefore, the absence of reliable relationships among the extractable content of heavy metals and the main soil properties usually involved in their immobilization was ascribed to two factors: (i) the weathering rate of the minerals comprising them, and (ii) at least for the unknown quote due to contamination, the chemical form in which the heavy metals arrived to the soil and the chemical reactions to which they are submitted, given the soil geochemical conditions like $\mathrm{pH}$, moisture, redox conditions, presence of complexing substances. For example, the availability of $\mathrm{Cr}$ and $\mathrm{Ni}$ present in antigorite depends on the weathering rate of the crystal lattice that, at sub-alkaline $\mathrm{pH}$, is expected to be low. Instead, for $\mathrm{Cu}, \mathrm{Pb}$, and $\mathrm{Zn}$, the extractable portion probably derived from recent anthropic additions in forms that were not immobilized through the redistribution among the main chemical/mineralogical phases, yet. The fact that $\mathrm{Pb}$ showed the highest proportion of extractability and abounded in the coarser separates was ascribed to the relatively high solubility of $\mathrm{Pb}$-hydroxides in sub-alkaline soils, as reported by Basta et al. (2005) and Chuan et al. (1996).

Biological and biochemical properties of the city soils

Besides detecting the amount of extractable heavy metals, it is important to assess if the levels of these elements may have negatively affected soil biology, so compromising soil functions. As extensively reported in the literature (e.g. Bastida et al., 2008; Schloter et al., 2003; da Silva Aragão et al., 2020), parameters like $\mathrm{C}$ biomass, basal respiration, $\mathrm{qCO}_{2}$, and enzyme activities are widely considered as proxies for soil quality as they are intimately linked to physicochemical parameters able to influence soil biological activity (Dantas Lopes et al., 2021; Khan et al., 2016; Lorenz \& Kandeler, 2005). Although basal respiration is not always considered a reliable indicator for heavy metal polluted soils (Romero-Freire et al., 2016), the mean $\sum \mathrm{CO}_{2}-\mathrm{C}$ of $551 \mu \mathrm{g} \mathrm{CO} \mathrm{CO}_{2}-\mathrm{C}$ $\mathrm{g}^{-1}$ for these urban soils was higher than the values found in the superficial horizon of vineyard soils (from 66.6 to $157.5 \mu \mathrm{g} \mathrm{CO}_{2}-\mathrm{C} \mathrm{g}^{-1}$ soil, Corti et al., 2007) and forest soils ( $434 \mu \mathrm{g} \mathrm{CO}_{2}-\mathrm{C} \mathrm{g}^{-1}$ soil, Cocco et al., 2013), located close to the city. Similarly, Decina et al. (2016) found that soil respiration rates decreased from urban soils to rural forest soils in the Boston metropolitan area and ascribed this trend to the soil management in the various situations, which are variably able to stimulate the microbial activity. The amount of $\mathrm{CO}_{2}-\mathrm{C}$ respired per unit of $\mathrm{C}_{\text {mic }}$ and time of respiration gives the $\mathrm{qCO}_{2}$ index of microbial activity linked to the soil environmental conditions, and relatively low $\mathrm{qCO}_{2}$ values indicate microbial adaptation to environmental soil conditions (e.g. Anderson \& Domsch, 1990, 1993; Hannachi et al., 2014; Moscatelli et al., 2007). The relatively low $\mathrm{qCO}_{2}$ values of the studied soils, with respect to $\approx 28 \mu \mathrm{g}$ $\mathrm{CO}_{2}-\mathrm{C} \mathrm{g}^{-1}$ assessed in city surrounding soils (Corti et al., 2007), indicated the high substrate use efficiency of the microbial community harbouring these soils (Anderson \& Domsch, 1989), which means a 
prevalence of anabolic over catabolic processes (Chander \& Brookes, 1991) promoted by relatively well-adapted microbial communities (Hannachi et al., 2014). Therefore, if more carbon is available for biomass production, a higher proportion of $\mathrm{C}_{\text {mic }}$ to TOC should occur (Anderson \& Domsch, 1986). In fact, while urban soils gave a mean $\mathrm{C}_{\text {mic }} / \mathrm{TOC}$ proportion of $\approx 1.3 \%$, it was $\approx 0.1 \%$ in the vineyard soils (Corti et al., 2007) and $\approx 0.5 \%$ in the forest soils (Cocco et al., 2013) close to the city. The high C use efficiency of the microbial communities harbouring the urban soils was probably due to their sub-alkaline $\mathrm{pHs}$, as acid conditions and nutrient limitations produce a reduction of microbial $\mathrm{C}$ use efficiency (Jones et al., 2019; Keiblinger et al., 2010; Sinsabaugh et al., 2013). However, it also means that soil microbial functions were not compromised by the contamination level reached by these soils in terms of heavy metals or other pollutants. As a further demonstration of this, the flowerbed of Porta Pia displayed the highest contents of available $\mathrm{Ni}$ and $\mathrm{Zn}$ and the highest $\mathrm{C}_{\text {mic }}$ content; in contrast, the flowerbed of Corso Carlo Alberto and the Palombella and Villa Beer parks showed the lowest $\mathrm{C}_{\text {mic }}$ concentration and not excessive extractable heavy metals, except for $\mathrm{Cu}$ at Palombella park.

Alkaline phosphatase activity was higher than acid phosphatase activity because of the sub-alkaline soil pH (Dick et al., 2000; Marinari \& Vittori Antisari, 2010; Zhan \& Sun, 2014). Enzymes like phosphatase, $\beta$-glucosidase, and urease are stabilized by humic and/ or clay colloids and preserve much of their activity (Busto \& Perez-Mateos, 2000; Gianfreda et al., 1995; Hayano \& Katami, 1977; Pająk et al., 2016; Rao et al., 2000). By comparing our data with those reported by Nannipieri et al. (2002), it appeared that the general enzyme activity of our soils was not depressed, except for the soil at Palombella park, where enzyme activities and $\mathrm{C}_{\mathrm{mic}}$ were the lowest, and the $\mathrm{qCO}_{2}$ the highest. For this soil, for decades close to a brick kiln, it is possible that it received elevated amounts of $\mathrm{Cu}$ and $\mathrm{Zn}$, whose availability was not efficiently reduced notwithstanding the sub-alkaline $\mathrm{pH}$; the low clay content was probably responsible for this (Aponte et al., 2020). Thus, we attribute the depressed enzyme activities and microbial conditions to the relatively high content of both available $\mathrm{Cu}$ and $\mathrm{Zn}$ and the lowest clay content. However, studies have found opposite correlations between enzyme activities and heavy metal contents (e.g. Aponte et al., 2020; Tang et al., 2020), probably because of the different analytical methods applied, pollution levels, soil properties, etc.

\section{Conclusions}

Many countries adopted regulatory guidelines establishing limits for the total content of metal(loid)s in the soil, but these guidelines do not differentiate soils of urban areas from soils earmarked for other uses. Thus, especially for urban soils of old-settled cities where metallurgy, construction, and other human activities have accumulated heavy metals in soil for centuries or millennia, the adoption of fixed limits for heavy metals concentration could make difficult to respect them. The proposed new index, ToA, has the advantage to represent a heavy metal risk assessment calibrated on the base of city material history and is a mobile limit that is subjected to decrease or increase depending on the care given to the urban soils. We tested this new index in the urban soils of an old-settled city like Ancona (Italy) and found that for five out of the seven considered elements $(\mathrm{Co}, \mathrm{Cr}, \mathrm{Cu}, \mathrm{Hg}$, and $\mathrm{Ni}$ ) $\mathrm{ToA}$ was lower, while for $\mathrm{Pb}$ and $\mathrm{Zn}$ it was higher than the limits reported by the Italian legislation. The proposed ToA allowed us recognizing nine over 18 soils with a multi-elemental critical situation and was therefore considered a valuable tool to highlight soils where it is more impellent to intervene to mitigate or avoid potential environmental concerns in old-settled cities. However, despite the total and available concentration of heavy metals in soil, the soil biological functions (microbial and enzyme activities) were maintained in most of the 18 situations, as well as soil ecological services (e.g. substrate for plant growth, organic carbon storage, water filtration, chemical and biochemical transformation) were ensured. Because of this, for a proper risk assessment in urban soils, we suggest considering both the content of available heavy metals and the conservation of soil functions and ecological services. However, we are aware that more research is needed before ToA or other risk assessment tools based on available heavy metal content could be adopted as regulatory limit. 
Authors' contribution The authors equally participated in writing the paper.

Funding Open access funding provided by Università Politecnica delle Marche within the CRUI-CARE Agreement. Funding of this project was obtained from the Ministry of Education, University and Research (2004079713) and from the Ancona Province (Project "Attività di indagine sul contenuto di metalli pesanti nei suoli urbani e delle implicazioni relative la costituzione del particolato atmosferico nelle città di Ancona, Falconara, Senigallia, Jesi e Fabriano").

Data availability The datasets generated and/or analysed during the current study are available from the corresponding author on reasonable request.

Code availability Not applicable.

\section{Declarations}

Conflicts of interest The authors declare no competing interests.

Ethical approval Not applicable.

Open Access This article is licensed under a Creative Commons Attribution 4.0 International License, which permits use, sharing, adaptation, distribution and reproduction in any medium or format, as long as you give appropriate credit to the original author(s) and the source, provide a link to the Creative Commons licence, and indicate if changes were made. The images or other third party material in this article are included in the article's Creative Commons licence, unless indicated otherwise in a credit line to the material. If material is not included in the article's Creative Commons licence and your intended use is not permitted by statutory regulation or exceeds the permitted use, you will need to obtain permission directly from the copyright holder. To view a copy of this licence, visit http://creativecommons.org/licenses/by/4.0/.

\section{References}

Abrahams, P. W. (2002). Soils: Their implications to human health. Science of the Total Environment, 291, 1-32.

Achakzai, K., Khalid, S., \& Bibi, A. (2015). Determination of heavy metals in agricultural soil adjacent to functional brick kilns: A case study of Rawalpindi. Science of Technological Development, 34, 122-129.

Acosta, J. A., Cano, A. F., Arocena, J. M., Debela, F., \& Martínez-Martínez, S. (2009). Distribution of metals in soil particle size fractions and its implication to risk assessment of playgrounds in Murcia City (Spain). Geoderma, 149, 101-109.

Adamu, A., Iyaka, Y. A., Mathew, J. T., Inobeme, A., \& Egharevba, H. O. (2017). Assessment of some heavy metal contamination and analysis of physicochemical parameters of surface soil within the vicinity of Minna railway station,
Niger State, Nigeria. Journal of Applied Life Sciences International, 10, 1-9.

Ajmone-Marsan, F., \& Biasioli, M. (2010). Trace elements in soils of urban areas. Water Air Soil Pollution, 213, 121-143.

Ajmone-Marsan, F., Biasioli, M., Kralj, T., Grčman, H., Davidson, C. M., Hursthouse, A. S., Madrid, L., \& Rodrigues, S. (2008). Metals in particle-size fractions of the soils of five European cities. Environmental Pollution, 152, 73-81.

Akoto, O., Ephraim, J. H., \& Darko, G. (2008). Heavy metals pollution in surface soils in the vicinity of abundant railway service workshop in Kumasi, Ghana. International Journal of Environmental Research, 2, 359-364.

Alexandrovskaya, E. I., \& Alexandrovskiy, A. L. (2000). History of the cultural layer in Moscow and accumulation of anthropogenic substances in it. CATENA, 41, 249-259.

Anderson, T. H., \& Domsch, K. H. (1986). Carbon link between microbial biomass and soil organic matter. In F. Megusar \& M. Gantar (Eds.), Perspectives in microbial ecology (pp. 467-471). Slovene Society for Microbiology, Ljubljana.

Anderson, T. H., \& Domsch, K. H. (1989). Ratios of microbial biomass carbon to total organic carbon in arable soils. Soil Biology and Biochemistry, 21, 471-479.

Anderson, T. H., \& Domsch, K. H. (1990). Application of ecophysiological quotients $\left(\mathrm{qCO}_{2}\right.$ and $\left.\mathrm{qD}\right)$ on microbial biomasses from soils of different cropping histories. Soil Biology and Biochemistry, 22, 251-255.

Anderson, T. H., \& Domsch, K. H. (1993). The metabolic quotient for $\mathrm{CO}_{2}\left(\mathrm{qCO}_{2}\right)$ as a specific activity parameter to assess the effects of environmental conditions, such as $\mathrm{pH}$, on the microbial biomass of forest soils. Soil Biology \& Biochemistry, 25, 393-395.

Aponte, H., Meli, P., Butler, B., Paolini, J., Matus, F., Merino, C., Cornejo, P., \& Kuzyakov, Y. (2020). Meta-analysis of heavy metal effects on soil enzyme activities. Science of the Total Environment, 737, 139744.

ARPAM (Agenzia Regionale per la Protezione Ambientale delle Marche). (2012). Sintesi degli studi epidemiologici analitici sui residenti a Falconara Marittima, Chiaravalle e Montemarciano. ARPAM, Dipartimento di Ancona, Servizio Epidemiologico Ambientale (pp 17).

Atzei, D., Fermo, P., Vecchi, R., Fantauzzi, M., Comite, V., Valli, G., Cocco, F., \& Rossi, A. (2019). Composition and origin of PM2.5 in Mediterranean Countryside. Environmental Pollution, 246, 294-302.

Balázs, H., Opara-Nadib, O., \& Beesea, F. (2005). A simple method for measuring the carbonate content of soil. Soil Science Society of America Journal, 69, 1066-1068.

Basta, N. T., Ryan, J. A., \& Chaney, R. L. (2005). Trace element chemistry in residual-treated soil: Key concepts and metal bioavailability. Journal of Environmental Quality, 34, 49-63.

Bastida, F., Zsolnay, A., Hernández, T., \& García, C. (2008). Past, present and future of soil quality indices: A biological perspective. Geoderma, 147, 159-171.

Begum, S., Adnan, M., Akhtar, N., Aziz, M. A., Yousaf, S., \& Tariq, A. (2015). Chemical investigation of soil and vegetation in the vicinity of brick kilns in Fateh Jang region of Pakistan. Journal of Himalayan Earth Science, 48, 32-41. 
Biasioli, M., Barberis, R., \& Ajmone-Marsan, F. (2006). The influence of a large city on some soil properties and metals content. Science of the Total Environment, 356, 154-164.

Bisht, G., \& Neupane, S. (2015). Impact of brick kilns' emission on soil quality of agriculture fields in the vicinity of selected Bhaktapur area of Nepal. Applied and Environmental Soil Science, 2, 1-8.

Blackmer, A. M., \& Bremner, J. M. (1977). Denitrification of nitrate in soils under different atmospheres. Soil Biology \& Biochemistry, 9, 141-142.

Bradl, H. B. (2004). Adsorption of heavy metals ions on soils and soils constituents. Journal of Colloid and Interface Science, 277, 1-18.

Brecciaroli, G., Cocco, S., Agnelli, A., Courchesne, F., \& Corti, G. (2012). From rainfall to throughfall in a maritime vineyard. Science of the Total Environment, 438, 174-188.

Bugnot, A. B., Hose, G. C., Walsh, C. J., Floerl, O., Frenche, K., Dafforn, K. A., Hanford, J., Lowe, E. C., \& Hahs, A. K. (2019). Urban impacts across realms: Making the case for inter-realm monitoring and management. Science of the Total Environment, 648, 711-719.

Bundy, L. G., \& Bremner, J. M. (1972). A simple titrimetric method for determination of inorganic carbon in soils. Soil Science Society of American Procedure, 36, 273-275.

Burghardt W (2017). Main characteristics of urban soils. In M. J. Levin, K.-H. J. Kim, J. L. Morel, W. Burghardt, P. Charzynski, R. K. Shaw, IUSS Working Group (Eds.), Soils Within Cities - Global approaches to their sustainable management - composition, properties, and functions of soils of the urban environment. Catena Soil Sciences, Schweizerbart Science Publishers

Busto, M. D., \& Perez-Mateos, M. (2000). Characterization of $\beta$-D-glucosidase extracted from soil fractions. European Journal of Soil Science, 51, 193-200.

Chander, K., \& Brookes, P. C. (1991). Effects of heavy metals from past applications of sewage sludge on microbial biomass and organic matter accumulation in a sandy loam and silty loam UK soil. Soil Biology and Biochemistry, 23, 927-932.

Cheng, H., Li, M., Zhao, C., Li, K., Peng, M., Qin, A., \& Cheng, $X$. (2014). Overview of trace metals in the urban soil of 31 metropolises in China. Journal of Geochemical Exploration, 139, 31-52.

Cheng, J., Li, Y., Gao, W., Chen, Y., Pan, W., Lee, X., \& Tang, Y. (2018). Effects of biochar on $\mathrm{Cd}$ and $\mathrm{Pb}$ mobility and microbial community composition in a calcareous soil planted with tobacco. Biology and Fertility of Soils, 54, 373-383.

Christoforidis, A., \& Stamatis, N. (2009). Heavy metal contamination in street dust and roadside soil along the major national road in Kavala's region, Greece. Geoderma, 151, 257-263.

Chuan, M. C., Shu, G. Y., \& Liu, J. C. (1996). Solubility of heavy metals in a contaminated soil: Effects of redox potential and $\mathrm{pH}$. Water, Air and Soil Pollution, 90, 543-556.

Cocco, S., Corti, G., Agnelli, A., \& Pirchio, F. (2007). Prime osservazioni sulla presenza di serpentino nei suoli del bacino plio-pleistocenico delle Marche. In C. Gessa, S. Lorito, G. Vianello, L. Vittori Antisari (Eds.) Atti del Convegno Nazionale della Società Italiana della Scienza del Suolo "Suolo Ambiente Paesaggio", (pp 41-51). Imola.

Cocco, S., Agnelli, A., Gobran, G. R., \& Corti, G. (2013). Changes induced by the roots of Erica arborea L. to create a suitable environment in a soil developed from alkaline and fine-texture marine sediments. Plant and Soil, 368, 297-313.

Corti, G., Cocco, S., Brecciaroli, G., Di Peco, D., Basili, M., Cioci, C., Ajmone Marsan, F., Biasoli, M., \& Hannachi, N. (2010). Attività di indagine sul contenuto di metalli pesanti nei suoli urbani e delle implicazioni relative la costituzione del particolato atmosferico nelle città di Ancona, Falconara, Senigallia, Jesi e Fabriano. Final Report of the project (year 2009) funded by Ancona Province Administration. Università Politecnica delle Marche.

Corti, G., Cocco, S., Agnelli, A., \& Basili, M. (2007). Suolo bulk e rizosferico in vigneti con differenti gestioni del suolo. Italus Hortus, 14, 367-371.

da Silva Aragão, O. O., de Oliveira-Longatti, S. M., de Castro Caputo Rufini, P. S. M., Rodrigues Carvalho, G., de Carvalho, T. S., \& de Souza Moreirade, F. M. (2020). Microbiological indicators of soil quality are related to greater coffee yield in the Brazilian Cerrado region. Ecological Indicators, 113, 106205.

Dantas Lopes, L., Junior Fontes, R. C., Pacheco Patto, E., \& Fernandes Ferreira, M. (2021). Shifts in microbial and physicochemical parameters associated with increasing soil quality in a tropical Ultisol under high seasonal variation. Soil and Tillage Research, 206, 104819.

Darmendrail, D. (2003). The French approach to contaminatedland management - Revision 1. BRGM/RP-52276-FR, pp 148

De Kimpe, C. R., \& Morel, J.-L. (2000). Urban soil management: A growing concern. Soil Science, 165(1), 31-40.

Decina, S. M., Hutyra, L. R., Gately, C. K., Getson, J. M., Reinmann, A. B., Short Gianotti, A. G., \& Templer, P. H. (2016). Soil respiration contributes substantially to urban carbon fluxes in the greater Boston area. Environmental Pollution, 212, 433-439.

Dick, W. A., Cheng, L., \& Wang, P. (2000). Soil acid and alkaline phosphatase activity as $\mathrm{pH}$ adjustment indicators. Soil Biology and Biochemistry, 32, 1915-1919.

Drouineau, G. (1942). Dosage rapide du calcaire actif du sol: Nouvelles donnes sur la séparation et la nature des fractions calcaires. Annales Agronomiques, 12, 441-450.

Dube, A., Zbytniewski, R., Kowalkowski, T., Cukrowska, E., \& Buszewski, B. (2001). Adsorption and migration of heavy metals in soil. Polish Journal of Environmental Studies, 10(1), 1-10.

Environment Agency. (2020). Derivation and use of soil screening values for assessing ecological risks. Report ShARE id26 (revised). Environment Agency, Horizon House, Deanery Road, Bristol, BS1 5AH. ISBN: 978-184911-397-7.

Eivazi, F., \& Tabatabai, M. A. (1988). Glucosidases and galactosidases in soils. Soil Biology and Biochemistry, 20, 601-606.

FAO (Food and Agricultural Organization of the United Nations) \& ITPS (Intergovernmental Technical Panel on Soils). (2015). Status of the World's Soil Resources (SWSR) - Main Report. Food and Agriculture Organization of the 
United Nations and Intergovernmental Technical Panel on Soils, Rome.

Fialova, D., Kremplova, M., Melichar, L., Kopel, P., Hynek, D., Adam, V., \& Kizek, R. (2014). Interaction of heavy metals ions with carbon and iron based particles. Materials, 7, 2242-2256.

Francová, A., Chrastný, V., Šillerová, H., Vítková, M., Kocourková, J., \& Komárek, M. (2016). Evaluating the suitability of different environmental samples for tracing atmospheric pollution in industrial areas. Environmental Pollution, 220, 286-297.

Gianfreda, L., DeCristofaro, A., Rao, M. A., \& Violante, A. (1995). Kinetic behaviour of synthetic organo- and organomineral-urease complexes. Soil Science Society of America Journal, 59, 811-815.

Gong, C., Ma, L., Cheng, H., Liu, Y., Xu, D., Li, B., Liu, F., Ren, Y., Liu, Z., Zhao, C., Yang, K., Nie, H., \& Lang, C. (2014). Characterization of the particle size fractions associated heavy metals in tropical arable soils from Hainan Island, China. Journal of Geochemical Exploration, 139, 109-114.

Groenenberg, J. E., \& Lofts, S. (2014). The use of assemblage models to describe trace element partitioning, speciation, and fate: A review. Environmental Toxicology and Chemistry, 33, 2181-2196.

Gupta, S. S., \& Bhattacharyya, K. G. (2012). Adsorption of heavy metals on kaolinite and montmorillonite: A review. Physical Chemistry Chemical Physics, 14, 6698-6723.

Haldar, S. K., \& Tišljar, J. (2014). Basic Mineralogy. In S. K. Haldar \& J. Tišljar (Eds.), Introduction to mineralogy and petrology (pp. 39-79). Elsevier.

Hannachi, N., Cocco, S., Fornasier, F., Agnelli, A., Brecciaroli, G., Massaccesi, L., Weindorf, D., \& Corti, G. (2014). Effects of cultivation on chemical and biochemical properties of dryland soils from southern Tunisia. Agriculture Ecosystems and Environment, 199, 249-260.

Hayano, K., \& Katami, A. (1977). Extraction of $\beta$-glucosidase activity from pea field soil. Soil Biology and Biochemistry, 9, 349-351.

Higgs, F. J., Mielke, H. W., \& Brisco, M. (1999). Soil lead at elementary public schools: Comparison between school properties and residential neighbourhoods of New Orleans. Environmental Geochemistry and Health, 21, 27-36.

Hu, B., Shao, S., Ni, H., Fu, Z., Hu, L., Zhou, Y., Min, X., She, S., Chen, S., Huang, M., Zhou, L., Li, Y., \& Shi, Z. (2020). Current status, spatial features, health risks, and potential driving factors of soil heavy metal pollution in China at province level. Environmental Pollution, 266, 114961.

Huang, G., Su, X., Rizwan, M. S., Zhu, Y., \& Hu, H. (2016). Chemical immobilization of $\mathrm{Pb}, \mathrm{Cu}$, and $\mathrm{Cd}$ by phosphate materials and calcium carbonate in contaminated soils. Environmental Science and Pollution Research, 23, 16845-16856.

Ishaq, M., Khan, M. A., Jan, F. A., \& Ahmad, I. (2010). Heavy metals in brick kiln located area using atomic absorption spectrophotometer: A case study from the city of Peshawar, Pakistan. Environmental Monitoring and Assessment, 166, 409-420.

Ismail, M., Muhammad, D., Khan, F. U., Munsif, F., Ahmad, T., Ali, S., Khalid, M., Haq, N. U., \& Ahmad, M. (2012). Effect of brick kilns emissions on heavy metal ( $\mathrm{Cd}$ and $\mathrm{Cr}$ ) content of contiguous soil and plants. Sarhad Journal of Agriculture, 28, 165-170.

ISO 10693 (1995) Soil quality-Determination of carbonate content-Volumetric method. International Organization for Standardization.

Jones, D. L., Cooledge, E. C., Hoyle, F. C., Griffiths, R. I., \& Murphy, D. V. (2019). pH and exchangeable aluminum are major regulators of microbial energy flow and carbon use efficiency in soil microbial communities. Soil Biology \& Biochemistry, 138, 107584.

Kabata-Pendias, A., \& Pendias, H. (2001). Trace elements in soils and plants. CRC Press.

Keiblinger, K. M., Hall, E. K., Wanek, W., Szukics, U., Hämmerle, I., Ellersdorfer, G., Böck, S., Strauss, J., Sterflinger, K., Richter, A., \& Zechmeister-Boltenstern, S. (2010). The effect of resource quantity and resource stoichiometry on microbial carbon use efficiency. FEMS Microbiology Ecology, 73, 430-440.

Khan, S., Cao, Q., Hesham, A.E.-L., Xia, Y., \& He, J.-Z. (2007). Soil enzymatic activities and microbial community structure with different application rates of $\mathrm{Cd}$ and $\mathrm{Pb}$. Journal of Environmental Sciences, 19, 834-840.

Khan, S., Mack, R., Castillo, X., Kaiser, M., \& Joergensen, R. G. (2016). Microbial biomass, fungal and bacterial residues, and their relationships to the soil organic matter $\mathrm{C} / \mathrm{N} / \mathrm{P} / \mathrm{S}$ ratios. Geoderma, 271, 115-123.

Kumar, K., \& Hundal, L. S. (2016). Soil in the city: Sustainably improving urban soils. Journal of Environmental Quality, $45,2-8$.

Kumpiene, J., Lagerkvist, A., \& Maurice, C. (2008). Stabilization of $\mathrm{As}, \mathrm{Cr}, \mathrm{Cu}, \mathrm{Pb}$ and $\mathrm{Zn}$ in soil using amendments-A review. Waste Management, 28, 215-222.

Kwiatkowska-Malina, J. (2018). Functions of organic matter in polluted soils: The effect of organic amendments on phytoavailability of heavy metals. Applied Soil Ecology, 123, $542-545$.

Lasat, M. M. (2001). Phytoextraction of toxic metals: A review of biological mechanisms. Journal of Environmental Quality, 31, 109-120.

Lavkulich, L. M., \& Wiens, J. H. (1970). Comparison of organic matter destruction by hydrogen peroxide and sodium hypochlorite and its effect on selected mineral constituents. Soil Science Society of America Journal, 34, 755-758.

Li, G., Sun, G. X., Ren, Y., Luo, X. S., \& Zhu, Y. G. (2018). Urban soil and human health: A review. European Journal of Soil Science, 69, 196-215.

Li, Y., Li, H. G., \& Liu, F. C. (2017). Pollution in the urban soils of Lianyungang, China, evaluated using pollution index, mobility of heavy metals and enzymatic activities. Environmental Monitoring and Assessment, 189, 34.

Li, Z., Ma, Z., Van der Kuijp, T. J., Yuan, Z., \& Huang, L. (2014). A review of soil heavy metal pollution from mines in China: Pollution and health risk assessment. Science of the Total Environment, 468-469, 843-853.

Liao, Z., Xie, J., Fang, X., Wang, Y., Zhang, Y., Xu, X., \& Fan, S. (2020). Modulation of synoptic circulation to dry season PM2.5 pollution over the Pearl River Delta region: An investigation based on self-organizing maps. Atmospheric Environment, 230, 117482. 
Liu, D., Li, Y., Ma, J., Li, C., \& Chen, X. (2016). Heavy metal pollution in urban soil from 1994 to 2012 in Kaifeng city, China. Water Air and Soil Pollution, 227, 154.

Liu, G., Juan Wang, J., Liu, X., Liu, X., Xiaosai, L., Ren, Y., Wang, J., \& Dong, L. (2018). Partitioning and geochemical fractions of heavy metals from geogenic and anthropogenic sources in various soil particle size fractions. Geoderma, 312, 104-113.

Ljung, K., Otabbong, E., \& Selinus, O. (2006). Natural and anthropogenic metal inputs to soils in urban Uppsala, Sweden. Environmental Geochemistry and Health, 28, 353-364.

Lorenz, K., \& Kandeler, E. (2005). Biochemical characterization of urban soil profiles from Stuttgart, Germany. Soil Biology \& Biochemistry, 37, 1373-1385.

Luo, X. S., Xue, Y., Wang, Y. L., Cang, L., Xu, B., \& Ding, J. (2015). Source identification and apportionment of heavy metals in urban soil profiles. Chemosphere, 127, 152-157.

Luo, X. S., Yu, S., Zhu, Y., \& Li, X. (2012). Trace metal contamination in urban soils of China. Science of the Total Environment, 421-422, 17-30.

Madrid, F., Díaz-Barrientos, E., \& Madrid, L. (2008). Availability and bio-accessibility of metals in the clay fraction of urban soils of Sevilla. Environmental Pollution, 156(3), 605-610. http://doi.org/10.1016/j.envpol.2008.06.023.

Madrid, L., Diaz-Barrientos, E., Ruiz-Cortés, E., Reinoso, R., Biasioli, M., Davidson, C. M., Duarte, A. C., Grčman, H., Hossack, I., Hursthouse, A. S., Kralj, T., Ljung, K., Otabbong, E., Rodrigues, S., Urquhartf, G. J., \& Ajmone-Marsan, F. (2006). Variability in concentrations of potentially toxic elements in urban parks from six European cities. Journal of Environmental Monitoring, 8, 1158-1165.

Malandrino, M., Abollino, O., Giacomino, A., Aceto, M., \& Mentasti, E. (2006). Adsorption of heavy metals on vermiculite: Influence of $\mathrm{pH}$ and organic ligands. Journal of Colloid and Interface Science, 299, 537-546.

Manta, D. S., Angelone, M., Bellanca, A., Neri, R., \& Sprovieri, M. (2002). Heavy metals in urban soils: A case study from the city of Palermo (Sicily), Italy. Science of the Total Environment, 300, 229-243.

Marinari, S., \& Vittori Antisari, L. (2010). Effect of lithological substrate on microbial biomass and enzyme activity in brown soil profiles in the northern Apennines (Italy). Pedobiologia, 53, 313-320.

Morel, J. L., Schwartz, C., Florentin, L., \& de Kimpe, C. (2005). Urban soils. In Hillel D. (Ed.), Encyclopedia of Soils in the Environment (pp. 202-208). Elsevier Ltd., Academic Press, London.

Moscatelli, M. C., Di Tizio, A., Marinari, S., \& Grego, S. (2007). Microbial indicators related to soil carbon in Mediterranean land use systems. Soil and Tillage Research, 97, 51-59.

Nannipieri, P., Kandeler, E., \& Ruggiero, P. (2002). Enzyme activities and microbiological and biochemical processes in soil. In R. G. Burns \& R. P. Dick (Eds.), Enzymes in the environment: activity, ecology and application (pp. 1-33). Marcel Dekker.

Naylo, A., Almeida Pereira, S. I., Benidire, L., El Khalil, H., Castro, P. M. L., Ouvrard, S., Schwartz, C., \& Boularbah, A. (2019). Trace and major element contents, microbial communities, and enzymatic activities of urban soils of
Marrakech city along an anthropization gradient. Journal of Soils and Sediments, 19, 2153-2165.

Nelson, D. W., \& Sommers, L. E. (1996). Total Carbon, Organic Carbon, and Organic Matter. In D. L. Sparks, A. L. Page, P. A. Helmke, R. H. Loeppert, P. N. Soltanpour, M. A. Tabatabai, C. T. Johnston, M. E. Sumner (Eds.), Methods of soil analysis, Part 3. Chemical methods (pp. 961-1010). American Society of Agronomy, Soil Science Society of America, Madison.

Ni, S., Ju, Y., Hou, Q., Wang, S., Liu, Q., Wu, Y., \& Xiao, L. (2009). Enrichment of heavy metal elements and their adsorption on iron oxides during carbonate rock weathering process. Progress in Natural Science, 19, 1133-1139.

Olsen, S. R., Cole, C. V., Watanabe, F. S., \& Dean, L. A. (1954). Estimation of available phosphorus in soils by extraction with sodium bicarbonate; Research report No. 939. U.S. Department of Agriculture

Otunola, B. O., \& Ololade, O. O. (2020). A review on the application of clay minerals as heavy metal adsorbents for remediation purposes. Environmental Technology \& Innovation, 18, 100692.

Padoan, E., Romè, C., \& Ajmone Marsan, F. (2017). Bioaccessibility and size distribution of metals in road dust and roadside soils along a peri-urban transect. Science of the Total Environment, 601-602, 89-98.

Pająk, M., Błońska, E., Frąc, M., \& Oszust, K. (2016). Functional diversity and microbial activity of forest soils that are heavily contaminated by lead and zinc. Water Air \& Soil Pollution, 227(9), 1-14.

Papa, S., Bartoli, G., Pellegrino, A., \& Fioretto, A. (2010). Microbial activities and trace element contents in an urban soil. Environmental Monitoring and Assessment, 165, 193-203.

Peganova, S., \& Edler, K. (2004). Zinc. In E. Merian, M. Anke, M. Ihnat, \& M. Stoeppler (Eds.), Elements and their compounds in the environment (2nd ed., pp. 1203-1239). Wiley-VCH.

Peng, L., Liu, P., Feng, X., Wang, Z., Cheng, T., Liang, Y., Lin, Z., \& Shi, Z. (2018). Kinetics of heavy metal adsorption and desorption in soil: developing a unified model based on chemical speciation. Geochimica Et Cosmochimica Acta, 224, 282-300.

Pons-Branchu, E., Ayrault, S., Roy-Barmana, M., Bordier, L., Borst, W., Branchu, P., Douville, E., \& Dumont, E. (2015). Three centuries of heavy metal pollution in Paris (France) recorded by urban speleothems. Science of the Total Environment, 518-519, 86-96.

Pouyat, R. V., Day, S. D., Brown, S., Schwarz, K., Shaw, R. E., Szlavecz, K., Trammel, T. L. E., \& Yesilonis, I. (2020). Urban Soils. In R. Pouyat, D. Page-Dumroese, T. PatelWeynand, \& L. Geiser (Eds.), Forest and rangeland soils of the United States under changing conditions. Cham: Springer. https://doi.org/10.1007/978-3-030-45216-2_7

Pouyat, R. V., Setälä, H., Szlavecz, K., Yesilonis, I. D., Cilliers, S., Hornung, E., Yarwood, S., Kotze, D. J., Dombos, M., McGuire, M. P., \& Whitlow, T. H. (2017). Introducing GLUSEEN: a new open access and experimental network in urban soil ecology. Journal of Urban Ecology, 3, jux2. https://doi.org/10.1093/jue/jux002

Quevauviller, P., Rauret, G., Lopez-Sanchez, J. F., Rubio, R., Ure, A. M., Muntau, H., Fiedler, H. D., \& Griepink, B. 
(1997). The certification of the extractable contents (mass fraction) of $\mathrm{Cd}, \mathrm{Cr}, \mathrm{Ni}, \mathrm{Pb}$ and $\mathrm{Zn}$ in sediment following a three-step sequential extraction procedure. CRM 601. Report EUR 17554 EN.

Rao, M. A., Violante, A., \& Gianfreda, L. (2000). Interaction of acid phosphatase with clays, organic molecules and organo-mineral complexes: Kinetics and stability. Soil Biology \& Biochemistry, 32, 1007-1014.

Rodrigues, S., Pereira, M. E., Sarabando, L., Lopes, L., Cachada, A., \& Duarte, A. (2006). Spatial distribution of total $\mathrm{Hg}$ in urban soils from an Atlantic coastal city (Aveiro, Portugal). Science of the Total Environmental, 368, 40-46.

Romero-Freire, A., Sierra Aragón, M., Martínez Garzón, F. J., \& Martín Peinado, F. J. (2016). Is soil basal respiration a good indicator of soil pollution? Geoderma, 263, 132-139.

Rossiter, D. G. (2007). Classification of urban and industrial soils in the world reference base for soil resources. Journal of Soils and Sediments, 7, 96-100. https://doi.org/10.1065/ jss2007.02.208

Sah, D., Verma, P. K., Kumari, K. M., \& Lakhani, A. (2019). Chemical fractionation of heavy metals in fine particulate matter and their health risk assessment through inhalation exposure pathway. Environmental Geochemistry and Health, 41, 1445-1458.

Schloter, M., Dilly, O., \& Munch, J. C. (2003). Indicators for evaluating soil quality. Agriculture Ecosystems \& Environment, 98, 255-262.

Shi, M., Min, X., Ke, Y., Lin, Z., Yang, Z., Wang, S., Peng, N., Yan, X., Luo, S., Wu, J., \& Wei, Y. (2021). Recent progress in understanding the mechanism of heavy metals retention by iron (oxyhydr) oxides. Science of the Total Environment, 752, 141930.

Shi-bao, C., Meng, W., Shan-shan, L., Zhong-qiu, Z., \& Wen-di, E. (2018). Overview on current criteria for heavy metals and its hint for the revision of soil environmental quality standards in China. Journal of Integrative Agriculture, 17, 765-774.

Simon, E., Vidic, A., Braun, M., Fábián, I., \& Tóthmérész, B. (2013). Trace element concentrations in soils along urbanization gradients in the city of Wien, Austria. Environmental Science and Pollution Research, 20, 917-924.

Sinsabaugh, R. L., Manzoni, S., Moorhead, D. L., \& Richter, A. (2013). Carbon use efficiency of microbial communities: Stoichiometry, methodology and modelling. Ecology Letters, 16, 930-939.

Sodango, T. H., Li, X., Sha, J., \& Bao, Z. (2018). Review of the spatial distribution, source and extent of heavy metal pollution of soil in China: Impacts and mitigation approaches. Journal of Health Pollution, 8, 53-70.

Sun, Y. B., Zhou, Q. X., Xie, X. K., \& Liu, R. A. (2010). Spatial sources and risk assessment of heavy metal contaminations of urban soils in typical regions of Shenyang China. Journal of Hazardous Materials, 174, 455-462.

Tabatabai, M. A. (1994). Soil Enzymes. In R. W. Weaver, S. Angle, P. Bottomley, D. Bezdicek, S. Smith, A. Tabatabai, A. Wollum (Eds.), Methods of soil analysis - part 2. Microbiological and biochemical properties (Number 5, pp. 775-833), SSSA Book Series. SSSA Inc, Madison, Wisconsin.
Tabatabai, M. A. (1982). Soil enzymes. In A. L. Page \& D. R. Keeney (Eds.), Methods of soil analysis - part 2. Chemical and microbiological properties (pp. 903-948), SSSA Book Series. SSSA Inc, Madison, Wisconsin.

Tang, J., Zhang, L., Zhang, J., Ren, L., Zhou, Y., Zheng, Y., Luo, L., Yang, Y., Huang, H., \& Chen, A. (2020). Physicochemical features, metal availability and enzyme activity in heavy metal-polluted soil remediated by biochar and compost. Science of the Total Environment, 701, 134751 .

Tepanosyan, G., Sahakyan, L., Belyaeva, O., \& Saghatelyan, A. (2016). Origin identification and potential ecological risk assessment of potentially toxic inorganic elements in the topsoil of the city of Yerevan, Armenia. Journal of Geochemical Exploration, 167, 1-11.

Tume, P., González, E., King, R. W., Cuitiño, L., Roca, N., \& Bech, J. (2018). Distinguishing between natural and anthropogenic sources for potentially toxic elements in urban soils of Talcahuano, Chile. Journal of Soils and Sediments, 18, 2335-2349.

Ugwu, I. M., \& Igbokwe, O. A. (2019). Sorption of heavy metals on clay minerals and Oxides: A review. In S. Edebali (Ed.), Advanced sorption process application (chapter 7, pp 127). IntechOpen.

Unda-Calvo, J., Ruiz-Romera, E., Fdez-Ortiz de Vallejuelo, S., Martínez-Santos, M., \& Gredilla, A. (2019). Evaluating the role of particle size on urban environmental geochemistry of metals in surface sediments. Science of the Total Environment, 646, 121-133.

United States Environmental Protection Agency. Available at: https://www.epa.gov/chemical-research/ecological-soilscreening-level (last view January 2021).

UN-United Nations (2018). $68 \%$ of the world population projected to live in urban areas by 2050, says UN. World Urbanization Prospects: The 2018 Revision, Online Edition. UN Department of Economic and Social Affairs, Population Division. https://www.un.org/development/ desa/en/news/population/2018-revision-of-worldurbanization-prospects.html.

Vance, E. D., Brookes, P. C., \& Jenkinson, D. S. (1987). An extraction method for measuring microbial biomass C. Soil Biology \& Biochemistry, 19, 703-707.

Vodyanitskii, Yu. N. (2016). Standards for the contents of heavy metals in soils of some states. Annals of Agrarian Science, 14, 257-263.

Vuorinen, A. H. (1993). Requirement of $p$-nitrophenol standard for each soil. Soil Biology \& Biochemistry, 25, 295-296.

Wang, G., Zhang, S., Zhong, Q., Xu, X., Li, T., Jia, Y., Zhang, Y., Peijnenburg, W. J. G. M., \& Vijver, M. G. (2018). Effect of soil washing with biodegradable chelators on the toxicity of residual metals and soil biological properties. Science of the Total Environment, 625, 1021-1029.

Wei, B., \& Yang, L. (2010). A review of heavy metal contaminations in urban soils, urban road dusts and agricultural soils from China. Microchemical Journal, 94, 99-107.

WHO (World Health Organization). (2016). Global report on urban health: equitable, healthier cities for sustainable development (pp. 241). WHO and UN (United Nations) Habitat.

Wiłkomirski, B., Sudnik-Wójcikowska, B., Galera, H., Wierzbicka, M., \& Malawska, M. (2011). Railway transportation 
as a serious source of organic and inorganic pollution. Water Air \& Soil Pollution, 218, 333-345.

Wu, Y. S., Fang, G. C., Lee, W. J., Lee, J. F., Chang, C. C., \& Lee, C. Z. (2007). A review of atmospheric fine particulate matter and its associated trace metal pollutants in Asian countries during the period 1995-2005. Journal of Hazardous Materials, 143, 511-515.

Wuana, R. A., \& Okieimen, F. E. (2011). Heavy metals in contaminated soils: a review of sources, chemistry, risks and best available strategies for remediation. ISRN Ecology, 2011, 1-20. ID402647.

Xian, Y., Wang, M., \& Chen, W. (2015). Quantitative assessment on soil enzyme activities of heavy metal contaminated soils with various soil properties. Chemosphere, 139, 604-608.

Xiao, R., Wang, S., Li, R., Wang, J. J., \& Zhang, Z. (2017). Soil heavy metal contamination and health risks associated with artisanal gold mining in Tongguan, Shaanxi, China. Ecotoxicology and Environmental Safety, 141, 17-24.

Xueqiu, W., Xuemin, L., Hui, W., Mi, T., Ruihong, L., \& Sheng, Z. C. (2020). Interpretations of $\mathrm{Hg}$ anomalous sources in drainage sediments and soil in China. Journal of Geochemical Exploration, 224, 106711. https://doi.org/10. 1016/j.gexplo.2020106711

Yuan, G. L., Sun, T. H., Han, P., Li, J., \& Lang, X. X. (2014). Source identification and ecological risk assessment of heavy metals in topsoil using environmental geochemical mapping: Typical urban renewal area in Beijing, China. Journal of Geochemical Exploration, 136, 40-47.

Yuan, X., Xue, N., \& Han, Z. (2021). A meta-analysis of heavy metals pollution in farmland and urban soils in China over the past 20 years. Journal of Environmental Science, 101, 217-226.

Yutong, Z., Qing, X., \& Shenggao, L. (2016). Distribution, bioavailability, and leaching of heavy metals in soil particle size fraction of urban soils (northeastern China). Environmental Science and Pollution Research, 23, 14600-14607.

Zhan, J., \& Sun, Q.-Y. (2014). Development of microbial properties and enzyme activities in copper mine wasteland during natural restoration. CATENA, 116, 86-84.

Zhang, H., Wang, Z., Zhang, Y., \& Hu, Z. (2012). The effects of the Qinghai-Tibet railway on heavy metals enrichment in soils. Science of Total Environment, 439, 240-248.

Zhang, Q., \& Wang, C. (2020). Natural and human factors affect the distribution of soil heavy metal pollution: A review. Water Air \& Soil Pollution, 231, 350.

Publisher's Note Springer Nature remains neutral with regard to jurisdictional claims in published maps and institutional affiliations. 